\title{
LA RELIGIOSIDAD DE LOS EXTRANJEROS EN JEREZ DE LA FRONTERA A TRAVÉS DE SUS TESTAMENTOS, 1392-1550
}

\author{
POR \\ José A. Mingorance RuIZ \\ Universidad Pablo de Olavide de Sevilla \\ jaminru@hotmail.com
}

\section{RESUMEN}

La presencia de extranjeros en Castilla en los momentos finales de la Edad Media y comienzos de la Modernidad no está suficiente estudiada en algunos lugares de dicho reino, caso de Jerez.

El acercamiento a la religiosidad de tales colectivos de inmigrantes es objeto de sumo interés y uno de los medios para realizarlo es el análisis de sus testamentos.

PALABRAS CLAVE: Edad Media; extranjero; religiosidad; testamento.

\section{FOREIGNERS' RELIGIOSITY AMONG HIS LAST WILLS IN JEREZ DE LA FRONTERA, 1392-1550}

\begin{abstract}
The presence of foreigners in Castile at the end of the Middle Ages and the beginning of Modernity has not been studied enough in some places of that kingdom: it is the case of Jerez de la Frontera.

The study of the religiosity of those immigrants is a very interesting subject for the historic knowledge and the analysis of their last wills becomes a very appropriate means to do that.
\end{abstract}

KEY WORDS: Middle Ages; foreigner; religiosity; last will.

$\begin{array}{ll}\text { Recibido/Received } & 06-01-2014 \\ \text { Aceptado/Accepted } & 15-12-2014\end{array}$

\section{INTRODUCCIÓN}

Es sabido que la denominación de extranjero se refería, en época finimedieval y hasta la centralización Ilevada a cabo por los Borbones en el siglo XVIII (con el Decreto de Nueva Planta), no sólo a los naturales de lo que hoy constituyen otros países o naciones (v.g. Francia, Inglaterra, etc.), sino que, en rigor, los naturales de la Corona de Aragón también eran considerados como tales en los territorios de la Corona de Castilla y viceversa. ${ }^{1}$ Por tanto, los catalanes,

1 Tomamos el concepto de Bello León, J. M. 1994. Extranjeros en Castilla (1474-1501): 9-10, Universidad de La Laguna. Incluso la hallamos en la documentación como sinónimo de forastero simplemente. Así, en AHMJF, AC, fo 299r., viernes 27 mayo de 1524, se titula "Segadores que cojen los estrangeros": el veinticuatro Francisco de Trujillo informa al Cabildo: "que los de la villa del Puerto de St $\underline{\underline{a}} M^{\underline{a}}$ vienen a esta çibdad a coger segadores y que es perjuyzio de los vesinos della porque encareçen el presçio...". En este caso, son "extranjeros" los vecinos de El Puerto. También creemos se refiere simplemente a habitantes de otros lugares valencianos, ${ }^{2}$ mallorquines, etc., deberían ser considerados como extranjeros en sentido estricto.

Abordar el análisis de la religiosidad de los extranjeros en Jerez de la Frontera no es tarea fácil, dada la inexistencia de estudios anteriores que nos pudieran servir de guía en dicha reflexión. ${ }^{3}$

(incluso comarcanos) el pregón de 5 de septiembre de 1530, Actas Capitulares, fo 327r.: "que se pregone que ningund huésped resçiba ningund estranjero... que ningund tavernero nin otra persona non sea osado de acoger en su casa nin mesón ningund estranjero...". El 13 de agosto de ese año, se había dado un pregón referido a la noticia de epidemia de peste en Galicia, Vizcaya, Barcelona y Valencia.

2 Hinojosa Montalvo, J. 1981. "Las relaciones comerciales entre Valencia y Andalucía en la Baja Edad Media", Actas // Coloquio Historia Medieval de Andalucía: 249-267, Sevilla.

3 No es así a otros niveles y espacios, donde hallamos aportaciones muy valiosas y que nos han ayudado mucho a enfrentarnos a esta cuestión, v.g. Alfonso Santorio, P. 1997. "Religiosidad y nobleza. La fundación de capellanías. Un ejemplo malagueño", en Religiosidad 
Nosotros hemos realizado una investigación que abarca desde 1392 (fecha en que se conserva el primer Protocolo Notarial en el Archivo Municipal de Jerez de la Frontera) hasta 1550. La elección de la fecha de comienzo viene impuesta por la disponibilidad de documentación en el Archivo de Jerez de la Frontera.

Ahora bien, hemos elegido 1550 como meta de nuestro análisis por dos motivos fundamentales. En primer lugar porque necesitábamos disponer de un volumen documental suficiente como para poder elaborar una serie que nos permitiese sacar conclusiones con una mínima validez sobre las cuestiones analizadas. Y ello implicaba echar mano de los registros de la primera mitad del siglo XVI ya que la documentación conservada de los siglos XIV y XV es muy escasa. En segundo término porque relacionamos nuestro estudio con la evolución de la política general del emperador Carlos y en particular con el cambio de orientación en la política de Castilla a partir de dicho año.

Los resultados de nuestra investigación proceden básicamente de los Protocolos Notariales del Archivo de Jerez, que reseñaremos AHMJF, APN (Archivo Histórico Municipal de Jerez de la Frontera, Archivo de Protocolos Notariales). Los años cuyos protocolos ha sido posible revisar han sido: $1392,1414,1424,1427,1429,1433,1446,1448,1470$, $1471,1475,1483,1484,1489,1490,1491,1492$, y de 1500 a 1550 la serie completa (aunque de algunos años la documentación conservada es mínima). Además las actas de los notarios no ofrecen demasiadas noticias sobre ese mundo espiritual del que indudablemente participaban tales inmigrantes. Únicamente podemos echar mano de una documentación de excepcional interés para acercarnos al mundo de las creencias y devociones de tales personajes, como son los testamentos. Ellos constituirán la base que, junto a la bibliografía, nos permitirán una aproximación a una realidad que no siempre se nos aparecerá como clara y contundente, antes bien pensamos que está algo difuminada desde la consideración de que los contratos no siempre van a estar reflejando la opinión, la creencia, el sentimiento real del otorgante, sino en multitud de ocasiones desde los estereotipos, frases hechas y parafernalia escriptoria de los notarios públicos.

Vamos a centrarnos en un aspecto fundamental a la hora de afrontar tal cuestión: la muerte y las celebraciones por las ánimas de los difuntos.

popular en España: 193-216, San Lorenzo del Escorial. Carlé, Mạ. C. 1993. Una sociedad del siglo XV. Los castellanos en sus testamentos, Buenos Aires. Domínguez Ortiz, A. 1981. Autos de la Inquisición de Sevilla (siglo XVII), Sevilla. Fernández Conde, F. J. 2011. La religiosidad medieval en España. Baja Edad Media (siglos XIV y XV). Oviedo. Miura Andrades, J. M. 1987. “Las fundaciones de la O. P. en Andalucía (1236-1591). Un análisis cronológico", en Actas del Primer Congreso Internacional sobre los Dominicos y el Nuevo Mundo: 73-99, Madrid. Pérez González, S. Ma. 2000. "Las Cofradías de Sevilla en el siglo xv: La Cofradía de la Sangre", en I Simposio sobre Hermandades de Sevilla y su Provincia: 29-45, Sevilla. Romero Abao, A. del R. 1989 "La fiesta del Corpus Christi en Sevilla en el siglo XV", en La religiosidad popular. Hermandades, romerías y santuarios: 19-32, Sevilla. Sánchez Herrero, J. 1992. "La Iglesia y la religiosidad en la diócesis de Zamora a finales del siglo XV" en Zamora, su entorno y América, Diputación de Zamora. Para el caso de Jerez: García Guzmán, Mạ del M. y Abellán Pérez, J. 1997. La religiosidad de los jerezanos según sus testamentos (siglo XV), Cádiz.

\section{EL TESTAMENTO}

El testamento constituye el acto en virtud del cual el testador por diferentes motivos declara ante notario y testigos cuáles son sus últimas voluntades. ${ }^{4}$

En todos los testamentos que hemos analizado (un total de 116, más cuatro que corresponden a cónyuges de extranjeros, y que son los de doña Teresa de Villavicencio, viuda de Hernando de Villavicencio Zacarías, genovés; ${ }^{5}$ Ana Núñez, mujer de Jácome Adornio, genovés; ${ }^{6}$ Catalina de Figueroa, viuda del jurado Françisco Adornio, genovés; ${ }^{7}$ Pedro Martines de Hinojosa, marido de Catalina de Espíndola, genovesa, ${ }^{8}$ y menos siete que se repiten en años distintos con algunas modificaciones: Pedro Perseva de la Cruz, genovés, en 1542 y 1547; ${ }^{9}$ su esposa Catalina la griega en 1542 y $1550 ;{ }^{10}$ Catalina Peçano, genovesa, en 1527 y 1549; $;^{11}$ Françisco Adorno en 1538 y 1545;12 Antono Marques, genovés, en 1536 y 1543; ${ }^{13}$ Hernando Tirado, genovés, en 1537 y 1537, ${ }^{14}$ y María Adorno, genovesa, en 1535 y 1537) ${ }^{15}$ aparece de manera explícita y fehaciente el miedo a la muerte, es decir, la percepción de tal momento como una realidad inexcusable y terrible, a la que nadie puede escapar y, frente a ese miedo, la esperanza en la salvación eterna que lleva a encomendarse a Dios, la Virgen y toda la corte celestial para que faciliten su camino a la gloria del paraíso.

Esos 116 testamentos registrados corresponden a 109 personas, ya que hay siete que testan en dos años distintos, y se reparten de manera desigual entre ambos sexos, pues frente a 88 que otorgan hombres, sólo hallamos 22 correspondientes a mujeres, es decir, una proporción de $80 \%$ frente a un $20 \%$.

En lo que se refiere a aspectos formales del documento hemos de reconocer que no hallamos diferencias ostensibles entre la redacción de unos y de otros, ni evolución a lo largo del período objeto de análisis. Bien es verdad que del siglo XV sólo disponemos de un testamento correspondiente a 1490 , pero las diferencias son mínimas: en este

4 Diccionario de Autoridades, 1739, p. 262, 2: “Declaración de la última voluntad, que hace una persona, disponiendo de sus bienes, y hacienda, e instituyendo heredero que suceda en ella después de su muerte".

5 AHMJF, APN, oficio 8, Gómez Patiño, fo 810rv., 24 de agosto de 1546.

6 AHMJF, APN, oficio 7, Luis de Llanos, fo 175rv 25 de febrero de 1525.

AHMJF, APN, oficio 2, Sebastián Gaitán, fo 588rv., 3 de agosto de 1506.

8 AHMJF, APN, Antón de la Zarza, fo 118r., 1 de agosto de 1492.

9 AHMJF, APN, oficio 10, Bartolomé Gil de Palencia, fo 1005rv., 16 de septiembre de 1542, y oficio 8, Gómez Patiño, fo 254v., 11 de marzo de 1547.

10 AHMJF, APN, oficio 5, Rodrigo de Rus, fo 1031rv., 27 de julio de 1542, y oficio 5, Rodrigo de Rus, fo ileg v., 2 de enero de 1550.

11 AHMJF, APN, oficio 8, Francisco del Mercado, fo 565rv., 21 de octubre de 1527, y oficio 2, Alonso Sarmiento, fo 911v., 17 de noviembre de 1549.

12 AHMJF, APN, oficio 7, Luis de Llanos, fo 163rv., 22 de febrero de 1538, y oficio 1, Francisco Román de Trujillo, fo 307v., 26 de junio de 1545.

13 AHMJF, APN, oficio 7, Luis de Llanos, fo 359v., 29 de abril de 1536 y oficio 7, Luis de Llanos, fo 477rv., 19 de junio de 1543.

14 AHMJF, APN, oficio 6, Francisco de Sanabria, fo 891rv., 17 de agosto de 1535, y oficio 3, Rodrigo de Cuenca, fo 416v., 9 de agosto de 1537.

15 AHMJF, APN, oficio 2, Alonso Sarmiento, fo 451v., 27 de junio de 1535, y oficio 2, Alonso Sarmiento, fo 728rv., 19 de octubre de 1537. 
caso señalar que el del XV presenta una redacción objetiva, mientras todos los pertenecientes al siglo XVı la tienen subjetiva. Las variaciones más relevantes tienen que ver con el número de disposiciones relativas a la cantidad de misas que se han de ofrecer por el alma del finado, y que guardan correspondencia directa con la capacidad económica del sujeto. La explicación de la afirmación anterior viene del hecho de que raramente el testamento es redactado por el otorgante (sólo hemos hallado un caso), sino por el notario y las fórmulas notariales se mantienen vigentes durante largos períodos de tiempo. ${ }^{16}$

Por lo demás, los testamentos responden a un esquema fijo que, reiteramos, no cambia de unos notarios a otros, ni tampoco con el paso del tiempo. Comienzan con una invocación, normalmente "En el nombre de Dios, amén", y continúan con los datos personales del intitulante: nombre, profesión y domicilio.

A continuación se suelen situar aquellas manifestaciones de la fe que se consideraban imprescindibles, en particular la creencia en la Trinidad; alusiones a la brevedad de la vida terrenal, así como a la ineludibilidad de la muerte y a la necesidad de estar preparado para la misma. Parte importante de tal preparación estaba constituida precisamente por el otorgamiento de últimas voluntades, cosa que se hace a "honor de Dios, la Virgen y toda la corte celestial para mi ánima salvar y mis herederos en paz y concordia dejar".

Normalmente se sitúa a continuación la declaración de los débitos, tanto de los deudores como de los acreedores del testador, cuestión esta que se cuida de manera escrupulosa, incluso en aquellos casos en que se ha olvidado el nombre del acreedor o del deudor, y siempre se encarga encarecidamente el cobro o el pago (según proceda) de las correspondientes cantidades, ${ }^{17}$ aunque en algunos casos se condona por diversos motivos toda la cantidad o parte de la misma.

La declaración de bienes ${ }^{18}$ que se poseen en el momento de testar no constituye una norma que se observe siempre

16 Esta conclusión es análoga a la expresada por Pérez González, S. Ma. 2005. Los laicos en la Sevilla bajomedieval. Sus devociones y cofradías: 83, Huelva, Universidad de Huelva, para el caso sevillano, y García Guzmán, Mạ del M. y Abellán Pérez, J. 1997, así como Sánchez Herrero, J. 2001. "Vivir y morir en Estepa en el siglo XVII". Actas de las IV Jornadas sobre Historia de Estepa. La vicaría eclesiástica de Estepa: 239-283, Estepa.

17 AHMJF, APN, oficio 5, Rodrigo de Rus, fo ileg v., 2 de enero de 1550: la genovesa Catalina la griega, casada con el curtidor genovés Pedro Perseva de la Cruz, testa en 1546, produciéndose la apertura del mismo cuatro años después. En él declara que le debe "vna muger que mora a la Puerta Rota que no sé su nonbre más de que es tributera de los herederos de Guillermo Conde de Gave..." seis reales de préstamo, teniendo en prenda por ello "dos almohadas de cama vasyas labradas con seda de grana en pedaço de lienço blanco que sirve de artes"; Bernala, morisca, tres reales también de préstamo; Juana Parrada, hermana de Juan Parrado, real y medio asimismo de préstamo; a una mujer "vieja que diz que es difunta que falleció en Sevilla e no me acuerdo de su nonbre" ocho reales y en prenda le dejó una manilla de oro "e sy no pareciere dueño se venda e se pague los ocho reales a mis herederos y lo que sobrare se dé en limosna al arca del Santísymo Sacramento de la dicha yglesia del Salvador" (donde ha de ser enterrada). Observamos una intención clara de ser exhaustivo en la relación de las deudas, al tiempo que constatamos la costumbre de entregar prendas como garantía de la devolución de los préstamos.

18 AHMJF, APN, oficio 3, Rodrigo de Cuenca, fo roto v., 26 de abril de 1522: el genovés Antono Roteño "Confieso que tengo en Génova, en el pago que dizen de Chamateos, vna huerta que heredé de mi padre. Yten... vn pedazo de tierra e byñas e olivar que heredé de mi padre, en el momento de redactar las últimas voluntades, mientras que sí se declara de manera fehaciente tanto las arras como la dote que aportó cada cónyuge en el momento de la boda (o se remite a la correspondiente carta dotal).

Como hemos apuntado algo que nunca falta en los testamentos es la declaración de dote y arras del matrimonio, como hace el portugués Juan Rodrigues, vecino en Santiago, quien declara que recibió en dote con Leonor Rodrigues dos aranzadas de viña en el pago de Macharnudo, más un solar en que está hecho un palacio en Santiago, más un portal y casapuerta, más 10.000 maravedís en ajuar; él por su parte llevó seis novillos cuarteños que podrían valer 3.000 maravedís. ${ }^{19}$

Las mandas ${ }^{20}$ constituyen el siguiente apartado del testamento, comenzando por encaminar el "ánima a Dios", y continuando con el lugar donde se desea ser sepultado, quiénes han de acompañar el entierro, la misa y vigilia de réquiem, así como las cantidades que se han de abonar por tales servicios. El resto de misas y exequias que se han de ofrecer para facilitar el acceso a la gloria del muerto se coloca inmediatamente después. Asimismo en este apartado se incluyen las mandas a familiares, amigos, conocidos, pobres, iglesias o monasterios, etc., que constituyen el deseo del testador y expresan sus sentimientos hacia tales personas o instituciones. Termina con las llamadas mandas forzosas, que son las que se destinan a las Órdenes de la Cruzada, la Trinidad y Santa Olalla, y a la iglesia mayor de Sevilla y, a veces, el Hospital de San Lázaro de la misma capital. Lo usual es mandar "la costumbre", es decir, un maravedí a cada una, pero en ocasiones se eleva la cantidad hasta los tres maravedíes e incluso más.

Las últimas partes del testamento están formadas por el nombramiento de herederos y de albaceas, la revocación de testamentos anteriores (dando validez sólo al último) y la data (tópica y cronológica), así como la relación de los testigos que asisten al acto. Termina con la firma del testador, algún testigo y el escribano público ante quien se realiza el documento.

Normalmente, como hemos apuntado, quien redacta dicho documento no es el testador, sino el escribano, aunque hemos encontrado alguno que tiene todas las trazas de ser autógrafo, basándonos para ello en el análisis de la caligrafía del texto (comparando la letra del mismo con la de la firma). ${ }^{21}$

que están del Marro. Yten confieso que tengo otra huerta en Génova, camino de la Onella, par de la villa. Yten... otro pedaço de tierra al dicho camino de Onella, que se dize Tovela. Yten tengo otro pedaço de tierra en Génova, arryba désta que se dize Aguafría. Yten confieso que me deven todas las rentas de trigo de todas las dichas heredades, mis guardadores de lo que han cobrado mando que todo se cobre".

19 AHMJF, APN, oficio 2, Sebastián Gaitán, fo $567 v$., 9 de septiembre de 1511.

20 Pérez González, S. Ma. 2005: 82, las clasifica en dos tipos: “unas religiosas (profesión de fe, ideas de temporalidad de la vida humana, la esperanza en la vida eterna, los medios para asegurarse la salvación) y otras de carácter material, dada la necesidad de que las últimas voluntades del testador se cumplieran estrictamente y su patrimonio se repartiese entre sus herederos".

${ }^{21}$ AHMJF, APN, oficio 1, Francisco Román de Trujillo, fo 310rv., 311r., 5 de junio de 1545: testamento del veinticuatro Francisco Adorno. 


\section{LA MUERTE Y LAS CONMEMORACIONES POR LOS DIFUNTOS}

En unos siglos en que la muerte era una realidad omnipresente (la mortalidad general estaba en índices en torno al 38 por mil; la mortalidad infantil en niveles de casi 200 por mil hasta finales del siglo $\mathrm{xIX},^{22}$ y la mortalidad catastrófica venía a aumentar los efectos de las dos anteriores debido a las guerras, epidemias y hambrunas y sus ciclos: recordemos los numerosos conflictos bélicos de Castilla en los siglos XIV y XV, así como la recurrencia de la peste, sobre todo la de los años centrales del Trescientos), y la esperanza de vida tan corta, la reflexión sobre tal aspecto de la vida de las sociedades del pasado constituye un elemento de primordial importancia para el análisis de los comportamientos colectivos de las mismas. El estudio de la relación del hombre con la muerte comporta unos elementos de análisis de gran interés histórico, antropológico y sociológico. ${ }^{23}$

A pesar del interés que poseen dichos estudios, es relativamente reciente la publicación de análisis sobre dicha realidad. ${ }^{24}$

Tomemos como ejemplo del sentimiento de aversión y miedo a la muerte las siguientes palabras y expresiones tomadas de algunos de los testamentos estudiados: "Enferma del cuerpo e sana de la voluntad... e temyendo la muerte e codiçiando la salvaçión de my ányma..."; 25 "Consyderando que nuestro redentor lehsu Christo por su dotrina evangélica a todo onbre (roto) presente vida por la ynçierta ora de la horrible muerte para que (roto) aparejados nos halle al camino para yr ante aquel juez justo a dar quenta y razón estrecha de nuestras obras y vida..."; 26 "...e

22 Dopico Gutiérrez del Arroyo, F. "Desarrollo económico y social y mortalidad infantil. Diferencias regionales (1860-1950)", en http://ddd. uab.cat/pub/dynamis/02119536v5-6p381.pdf.

${ }^{23}$ Jaime Piqueras, J. 2012. “Disposiciones espirituales y modelo familiar en los testamentos medievales valencianos: una aproximación económica, 1381-1450", HID 39: 241-258. En dicho artículo el autor explica la escasa frecuencia de tales estudios: "Las vidas cotidianas, mucho más oscuras que las estructuras institucionales, aun habiendo sido objeto de interés desde fechas relativamente recientes, no poseen el atractivo ni el impacto de otro tipo de análisis y sin embargo, han generado actitudes culturales que llegan hasta nosotros generación tras generación, indicándonos la conveniencia de enfocar la cuestión desde el diálogo conceptual entre historia y antropología, un diálogo que propicia la riqueza de informaciones que proporcionan las fuentes históricas y en particular los testamentos, que informan sobre la relación de una sociedad y sus individuos con la muerte".

${ }^{24}$ Martínez Gil, F. 1996. La muerte vivida: muerte y sociedad en Castilla durante la Baja Edad Media, Universidad de Castilla la Mancha, Madrid. García Fernández, M. 1996. Los castellanos y la muerte. Religiosidad y comportamientos colectivos en el Antiguo Régimen, Junta de Castilla-León, Valladolid. Arranz Guzmán, A. 1986. “La reflexión sobre la muerte en el medievo hispánico, ¿continuidad o ruptura?", En la España Medieval V, v. I, Universidad Complutense de Madrid. Bejarano Rubia, A. 1988. "La elección de sepultura a través de los testamentos medievales murcianos", Miscelánea Medieval Murciana 15, Universidad de Murcia. Pons Alós, V. 1987. Testamentos valencianos en los siglos XIIIXVI. Testamentos, familia y mentalidades en Valencia a finales de la Edad Media, Tesis doctoral inédita, Valencia. Ibídem. 1995. "Documento y sociedad: el testamento en la Valencia medieval", Estudis Castellonencs 6: 1101 y ss, Castelló.

25 AHMJF, APN, oficio 5, Rodrigo de Rus, fo roto v., 12 de septiembre de 1548: testamento de Catalina Mendes, portuguesa casada con el mercader Rodrigo Álvares, vecina en la collación de San Miguel.

26 AHMJF, APN, oficio 1, Francisco Román de Trujillo, fo 32v., 7 de febrero de 1523: testamento de Batysta Bone, tonelero genovés, vecino en San Miguel. themiendo la muerte e acabamiento [deste] mundo, que es breve e muy falleçedero, de lo qual segund el glorioso apóstol ningún onbre bivo en este siglo se puede excusar...". ${ }^{27}$

\section{Finalidad del testamento}

En todos los casos hallados el objetivo del testamento es preparar el alma para su presentación ante Dios, así como ordenar su hacienda con el objetivo de poner paz entre sus herederos, evitando las posibles disputas por cuestiones de división de la herencia. Para ello, las fórmulas que se utilizan son muy claras y significativas: "... codiçiando la salvaçión de my ányma por la encamynar a la gloria celestial para donde fue criada Por ende otorgo... a honor de Dios nuestro Señor e de su bendita madre con toda la corte celestial my postrimera voluntad por my ányma salvar e mis herederos en paz dexar"; ${ }^{28}$ "... codiçiando poner la mi ánima en la más santa e verdadera carrera que yo pueda haser para la salvar e la llegar a Dios nuestro Señor e a la santa gloria de parayso. Otorgo... mi testamento a onor de Dios nuestro Señor e de la gloriosa Virgen María nuestra Señora, su madre, con toda la corte celestial, por mi ánima salvar e mis herederos en pas y buena concordia dexar, en la forma siguiente". ${ }^{29}$

Comprobamos que, con ligeras variantes, las fórmulas son repetitivas: se trata de alcanzar la salvación eterna y, para ello, es necesario además de haber llevado una vida honrada, estar preparado y eso significa ordenar el testamento. Dicho documento se redacta a honor de Dios (a veces se utiliza la palabra "loor", en lugar de honor, pero el significado es muy similar), de la Virgen (a quien muchos consideran su abogada o intercesora ante la justicia divina), ${ }^{30}$ y de todos los santos y santas de la corte celestial.

En algunos de los testamentos revisados faltan algunas de tales encomendaciones, normalmente se trata de los integrantes de la corte celestial, a veces de la Virgen, pero somos de la opinión que tales diferencias deben obedecer más a formulismos propios de cada escribano que a diferencias ideológicas entre los testadores, cuyo perfil religioso nos parece idéntico en todos los casos.

Además está la cuestión de la finalidad de buscar la paz y concordia de los herederos. Evidentemente dejando de manera explícita los bienes repartidos entre los mismos, resultaría más difícil que estallaran rencillas entre los mismos por tales motivos, pero reconocemos que ésta -siendo

27 AHMJF, APN, oficio 3, Rodrigo de Cuenca, fo 175v., 22 de abril de 1521: testamento del veinticuatro Leonís Adornio, corregidor y alcaide de Arcos de la Frontera, vecino en San Marcos.

28 AHMJF, APN, oficio 5, Rodrigo de Rus, fo roto v., 12 de septiembre de 1548: testamento de Catalina Mendes, portuguesa mujer del mercader Rodrigo Álvares, vecina en San Miguel.

29 AHMJF, APN, oficio 3, Rodrigo de Cuenca, fo 319v., 27 de julio de 1528: testamento de don Luys de Anpuñán, gentilhombre de su majestad, milanés vecino de El Puerto y estante en Jerez.

30 AHMJF, APN, oficio 7, Luis de Llanos, fo 359v., 29 de abril de 1536: testamento del odrero genovés Antono Marques, vecino en San Marcos "... Ilevar a la gloria del parayso y encomiendo la mi ánima a la Virgen Santa María, nuestra señora, a quien yo tengo por mi señora e abogada en todos mis fechos, a la qual suplico ruegue a su hijo preçioso, mi señor lehsu Christo, me quiera perdonar mis pecados y llevar mi ánima a su santa gloria, amén. Hago e hordeno este mi testamento e postrimera voluntad en la forma e manera siguiente...". 
condición necesaria- no es suficiente para evitar las disputas en los casos de desacuerdo en el reparto de los bienes que pertenecieron al finado.

En lo que se refiere a los matrimonios no hemos encontrado la redacción simultánea del testamento por parte de ambos cónyuges. Lo que más se le acerca es el caso de la pareja formada por el curtidor genovés Pedro Perseva de la Cruz y su esposa Catalina la griega, que otorgan testamento el mismo año, 1542, ${ }^{31}$ ella el 27 de julio y él con fecha 16 de septiembre pero, aunque declaran hallarse enfermos, no fallecen dicho año, pues vuelven a testar: él en 1547 y ella en 1550 (aunque en realidad ella testa con fecha 7 de junio de 1546 y la apertura del testamento se realiza cuatro años después).

\section{Estado físico de los intitulantes}

Sobre este aspecto del testamento, usualmente se entiende que se testa cuando se considera cercana la hora de la muerte (por enfermedad u otra causa), pero esto no siempre es así y a veces se redactan las últimas voluntades estando perfectamente sano. Por ello vamos a distinguir entre los que testan hallándose enfermos y los que lo hacen gozando de salud.

De los 116 testamentos analizados, ciento nueve corresponden a personas que se encuentran enfermas en el momento de redactarlos (94\%), y sólo siete lo hacen hallándose en buenas condiciones físicas (lo que representaría sólo un escaso seis por ciento del total).

Suponemos (ya que la documentación no lo explicita) que, en tales momentos de agonía, el enfermo se hallaría rodeado por sus familiares más directos, así como por algunos amigos y vecinos, y con seguridad por un sacerdote, que estaría encargado de dispensarle los últimos sacramentos (confesión y eucaristía y, sobre todo, la extremaunción). La presencia del clérigo la podemos colegir, v.g. de la relación de testigos del acto, como Alonso Garçía Naranjo, clérigo presbítero, testigo en el testamento de Juan Brut ${ }^{32}$ (en 1547, aunque éste testó hallándose sano porque iba a realizar un viaje a Inglaterra), o Pedro Sanches Corvacho, también clérigo en el de Berenguela Gentil en $1546 .{ }^{33}$ En total hemos registrado la presencia como testigos de 21 clérigos en los 116 testamentos analizados. Uno de los más repetidos es el clérigo y capellán del Hospital de la Misericordia, Atanasio Rodrigues, al que registramos como testigo en seis testamentos al menos (en 1540 el de Juan Martín; ${ }^{34}$ en 1536 los de Juani Anes, ${ }^{35}$ Antón (apellido roto) ${ }^{36}$ y Lorenço Anes; ${ }^{37}$ en

31 AHMJF, APN, oficio 10, Bartolomé Gil de Palencia, fo 1005rv., 16 de septiembre de 1542: Pedro, y oficio 5, Rodrigo de Rus, fo 1031rv., 27 de julio de 1542: Catalina.

32 AHMJF, APN, oficio 12, Martín de la Cruz, fo 328rv., 17 de abril de 1547.

${ }^{33}$ AHMJF, APN, oficio 8, Gómez Patiño, fo 292rv., 30 de marzo de 1546.

${ }^{34}$ AHMJF, APN, oficio 5, Rodrigo de Rus, fo 405v., 12 de abril de 1540.

35 AHMJF, APN, oficio 6, Francisco de Sanabria, fo 507 rv., 20 de junio de 1536

${ }^{36}$ AHMJF, APN, oficio 6, Francisco de Sanabria, fo 708v., 30 de agosto de 1536.

${ }^{37}$ AHMJF, APN, oficio 5, Rodrigo de Rus, fo $474 \mathrm{v}$., 30 de mayo de 1536.
1534 el de Pedro Alegrete ${ }^{38}$ y en 1532 el de Pedro Gonçales: ${ }^{39}$ todos ellos otorgan testamento en dicha institución).

La presencia de amigos y vecinos la podemos deducir asimismo de las listas de testigos, donde a veces registramos cómo se tiene especial preferencia por los compatriotas y artesanos del mismo oficio. ${ }^{40}$

Reiteramos que lo usual es otorgar testamento encontrándose enfermo por el temor a la muerte que se ve como algo inminente y la necesidad de preparar el alma para presentarse ante Dios, así como la de ordenar el patrimonio entre sus herederos. Nunca se cita la enfermedad que aqueja al testador, pero sí que se recoge dicho estado como elemento básico a la hora de redactar las últimas voluntades. ${ }^{41}$

Dicha enfermedad incapacita en ocasiones para redactar personalmente el testamento, lo que conlleva el apoderamiento a una tercera persona en quien se posee la suficiente confianza para que en su nombre realice dicho acto de últimas voluntades. Así ocurre en 1537 con el tonelero genovés Juan Batista Pelufo, vecino en la collación de San Dionisio, quien comienza el documento afirmando que "por quanto al presente yo estoy en dispusyçión de no poder faser mi testamento e última voluntad, e confiando en Françisco de Torres, vesino desta çibdad, hará e ordenará el dicho mi testamento segund e commo yo con él lo he comunicado..., por la presente otorgo e conosco... mi poder... al dicho Françisco de Torres espeçialmente... faser e ordenar el dicho mi testamento...". ${ }^{42}$

Los padecimientos pueden asimismo redundar en la incapacidad para firmar en el registro del notario el correspondiente testamento, lo que se traduce en la necesidad de pedir a algún testigo que lo haga en su nombre. Es lo que documentamos en algunos de tales documentos. ${ }^{43}$

Ese momento en que se ve cercana la muerte, es la ocasión de referirse a los gastos ocasionados por la enfermedad que se padece y ordenar que se abone dicho importe a quien

38 AHMJF, APN, oficio 6, Francisco de Sanabria, fo $358 \mathrm{v}$., 10 de abril de 1534.

39 AHMJF, APN, oficio 6, Francisco de Sanabria, fo 1001rv., 30 de setiembre de 1532

40 AHMJF, APN, oficio 4, Juan Rodríguez, fo $59 \mathrm{v} ., 9$ de enero de 1526: el calderero francés Antón Françés, estante en la ciudad, otorga testamento en 1526 ante el notario Juan Rodríguez, siendo testigos del mismo el escribano Françisco de Vera (que firmó por el otorgante porque no sabía escribir), el calderero Antón Garçía (en cuya casa se redacta el documento), los franceses Fernán Guillén (relojero), y Juan Françés y Juan Bastián (caldereros ambos), vecinos y estante en Jerez.

41 AHMJF, APN, oficio 2, Alonso Sarmiento, fo 728rv., 19 de octubre de 1537: doña María Adorno, genovesa, mujer del veinticuatro Françisco Adorno de Hinojosa, vecina en la collación de San Marcos: "estando en vnas casas de la morada de Françisco Adorno de Hinojosa, en presençia de mí Alonso Sarmiento,... paresçió doña María Adornio, muger del dicho... estando (ilegible) echada en vna cama, gravada de çierta enfermedad segund por ella pareçía, e dio e presentó a mí el dicho escrivano vn papel çerrado e sellado, el qual dixo que hera su testamento e postrimera voluntad e por tal dixo que lo presentava e presentó a mí el dicho... la qual dixo que dexava e dexó por sus herederos e albaceas a los en ella contenidos e que revocava e revocó todos los otros testamentos que hasta agora avía hecho...".

42 AHMJF, APN, oficio 6, Francisco de Sanabria, fo 823v., 6 de octubre de 1537.

43 AHMJF, APN, oficio 7, Luis de Llanos, fo 477rv., 19 de junio de 1543: Antono Marques, odrero genovés, vecino de Jerez, quien lo pide al escribano Juan de Çea "porque dixo que no podía firmar con la enfermedad que tenía". 
lo ha soportado. Así lo hace el flamenco Antono de Prince, ${ }^{44}$ vecino de Amberes, quien declara que “... el dicho Ximón de Orique de sus propios dineros gasta y a gastado y a de gastar en mi enfermedad e dietas y mediçinas y mantenimiento. Mando y es mi voluntad que todo aquello que el dicho Ximón de Orique jurare e declarare que a gastado... se le pague de mis bienes" y, si no basta, acudan a sus padres. Ximón de Orique es uno de sus albaceas encargado de determinar el número de honras y exequias que se le han de hacer.

Pasemos ahora a los redactan su testamento hallándose sanos. ¿Cuáles son las causas que llevan a estos siete personajes a testar encontrándose bien?

En primer lugar citaremos el caso de las personas que se hallan a punto de profesar en una orden religiosa, es decir, han acabado el período de inserción en la vida monástica que se conoce con el nombre de noviciado y están decididos a prometer la observancia de los votos canónicos de pobreza, castidad y obediencia en una determinada orden religiosa. ${ }^{45}$

En segundo lugar hemos de citar los casos referidos a la realización de viajes de larga distancia que conllevaban la asunción de una gran cantidad de riesgos, que incluían desde el asalto por parte de corsarios y piratas (y la consiguiente pérdida de la carga y la mercancía e, incluso, de la propia libertad convirtiéndose en cautivo) hasta la muerte (por la acción de los elementos o de un ataque pirático). De este tipo hemos registrado asimismo tres casos: uno que corresponde al mercader inglés Juan Brut (casado con Ynés Garçía, jerezana hija del portero del cabildo Françisco Garçía de las Cañas), que antes de realizar un viaje a Inglaterra decide otorgar testamento; ${ }^{46}$ un segundo al mercader genovés Clemente de Prementorio, estante en la ciudad, quien en 1530 otorga su testamento; ${ }^{47}$ y el tercero al gentilhombre de su majestad don Luys de Anpuñán (milanés hijo del conde de Anpuñán) que quiere embarcarse con destino a las Indias, en un viaje aún más arriesgado que el de Inglaterra, pues a las dificultades y mayor longitud de la travesía se unían los peligros de lo desconocido, de lo que estaba por descubrir, conquistar y colonizar. ${ }^{48}$

La tercera cuestión que se debe tener en cuenta en este aspecto es el referente a los peligros que comportaba el dar

44 AHMJF, APN, oficio 7, Luis de Llanos, fo 320rv., 30 de noviembre de 1546: "estante e residente al presente en la... çibdad de Xeres de la Frontera en casa de Lazarena Martínez, muger de Crespín Hac", en la collación de San Miguel.

45 AHMJF, APN, oficio 3, Rodrigo de Cuenca, fo 517rv., 24 de agosto de 1536. De éstos hemos hallado dos casos: uno que corresponde a Bernal de Bridales, francés natural de Olorón y estante en Jerez de la Frontera "frayle noviçio en el monesterio de nuestra Señora Santa María de la Difinçión de la Horden de Cartuxa...". El otro en oficio 5, Rodrigo de Rus, fo 1073rv., 17 de agosto de 1539: Benito Restrojo, portugués, novicio de la Orden del santo de Asís.

${ }^{46}$ AHMJF, APN, oficio 12, Martín de la Cruz, fo 328rv., 17 de abril de 1547.

47 AHMJF, APN, oficio 8, Francisco del Mercado, fo 319v., 6 de abril de 1530: "... estando sano del cuerpo y de la voluntad y porque yo vo fuera desta çibdad a çiertas partes e lugares sobre la mar y porque lo más çierto que los honbres tienen es el morir, y para esto es neçesario que los honbres dispongan su conçiençia por saluar su ánima e la llevar a Dios nuestro Señor a su santa gloria y parayso, para donde fue criada, otorgo e conosco que ago he hordeno este mi testamento...".

48 AHMJF, APN, oficio 3, Rodrigo de Cuenca, fo 319v., 27 de julio de 1528 . a luz en unos tiempos en que la atención a las parturientas casi se ceñía en exclusiva a la presencia de una partera (además de las mujeres de la familia con experiencia en tales trances). La muerte por causas adscribibles al parto o postparto eran bastante frecuentes y ello llevaba a algunas mujeres a otorgar testamento antes de enfrentarse al alumbramiento de un hijo. ${ }^{49}$

Algún caso no nos resulta fácil de explicar, pues no se encuentra reflejado en ninguna de las situaciones anteriores. Es el testamento del tonelero genovés Lorenço Panel, quien lo otorga en $1546,{ }^{50}$ declarando hallarse sano del cuerpo y de la voluntad..., pero por lo demás seguimos hallando otros contratos suyos hasta el año 1550 en que registramos su fallecimiento. Deducimos que simplemente lo otorgó por tranquilidad propia, para descanso de su alma de tener preparado su camino al cielo y perder el miedo a morir abintestato.

Frente a la declaración del mal estado físico del intitulante, es de resaltar que en todos los casos se hace mención de la buena salud mental en que se halla el mismo, con expresiones del tipo “... y sano de la voluntad y en mi seso y buena memoria tal que Dios nuestro Señor me lo quiso dar... "; ;1 "estando con enfermedad corporal y en mi seso e buena memorya y conplido entendimiento natural...". ${ }^{52}$ Todas ellas hacen referencia al buen estado síquico del individuo, con alusión a su memoria, entendimiento, juicio, seso,..., que se halla en similar estado al que Dios le proporcionó en el momento del nacimiento. La explicación es muy sencilla: se trata de que tenga validez jurídica lo ordenado en dicho testamento.

En los referidos casos de buen estado físico se hace mención a ambos de la manera que sigue: “... estando sano del cuerpo e del entendimiento..." 53 (antes de emprender viaje a Inglaterra); "... antes de aver fecho profiçión e con yntençión de la haser en el dicho monasterio, estando sano del cuerpo e de la voluntad..." 54 (antes de profesar en el monasterio de Cartuja); “... estando sano del cuerpo y de la voluntad y porque yo vo fuera desta çibdad a çiertas partes e lugares sobre la mar..."55 (antes de iniciar un viaje marítimo).

49 AHMJF, APN, oficio 7, Luis de Llanos, fo 1228rv., 10 de diciembre de 1521: doña Ysabel Despíndola, genovesa, mujer de Íñigo López de Carrizosa, vecina en San Juan, quien declara al otorgar testamento que se halla sana del cuerpo y de la voluntad, etc., y nombra como heredero "el póstomo o póstoma de que yo estoy ensynta del dicho Yñigo Lopes de Carrizosa, my marido, al qual dexo y establesco por mi legítimo e universal heredero en todos mis bienes; e sy el dicho póstomo o póstoma de que yo estoy ensynta non naçiere ni saliere a luz ni biviere, mando y quiero y es mi voluntad que todos mis bienes rayzes e muebles e semovientes los aya e herede el dicho Yñigo Lopes de Carrizosa, mi marido,...".

50 AHMJF, APN, oficio 11, Leonís Álvarez, fo 825v., 11 de junio de 1546.

51 AHMJF, APN, oficio 7, Luis de Llanos, fo 237v., 26 de julio de 1548: testamento del portugués Juan Martín, vecino en Santiago, en la calle Pozo del Olivar.

52 AHMJF, APN, oficio 1, Francisco Román de Trujillo, fo 75rv., 15 de junio de 1540: testamento del flamenco Françisco Martín, vecino en San Salvador.

53 AHMJF, APN, oficio 12, Martín de la Cruz, fo 328rv., 17 de abril de 1547: testamento de Juan Brut, mercader inglés vecino de Bristol y estante, que marcha de viaje a su país.

54 AHMJF, APN, oficio 3, Rodrigo de Cuenca, fo 517rv., 24 de agosto de 1536: Bernaldo de Bridales.

55 AHMJF, APN, oficio 8, Francisco del Mercado, fo 319v., 6 de abril de 1530: Clemente de Prementorio. 


\section{La confesión de las verdades católicas}

Sobre esta cuestión no se hallan demasiadas noticias en los testamentos, salvo la referencia casi obligada a la Trinidad y la ya comentada de efectuar dicho acto en honor de Dios, la Virgen y la corte celestial. Veamos algunas de las fórmulas usuales para el caso: "En el nonbre de Dios fase su testamento Juan Peres Peçano, vesino desta çibdad en la collaçión de San Juan..."; "En el nonbre de Dios e de la Virgen gloriosa sin mansylla alguna nuestra Señora santa María, su madre, amén..."; 57 "En el nonbre de Dios, amén... [creyendo] firme e verdaderamente en la Santysima Trenidad, que es Padre [e Hijo] e Espíritu Santo, tres personas, vn solo Dios verdadero, trino en personas, vno en esençia, que bive e reyna por syenpre syn fyn..."; $; 8$ lo usual es la referencia a la Trinidad "Padre e Hijo y Espíritu Santo, tres personas, vna esençia divina que bive e reyna para syenpre jamás", 59 o esta otra "... creyendo firmemente en la Santísima Trinydad y fe católica commo todo fiel christiano lo tiene e debe creer... Por ende otorgo... a honor de Dios nuestro Señor e de su bendita madre con toda la corte celestial...", ${ }^{60}$ seguida por " $a$ onor e reverençia de Dios nuestro Señor e de nuestra Señora santa María, su bendita madre, con toda la corte celestial". ${ }^{61}$

Comprobamos que las fórmulas son bastante similares y todas tratan de poner de relieve la fe del testador en las verdades fundamentales de la religión católica, es decir, Dios (y con ello la Trinidad), la Virgen y los santos (en oposición a la naciente reforma protestante).

\section{La muerte y el entierro}

La muerte constituye ese momento doloroso, terrible, de la existencia humana en que ésta deja de continuar existiendo para, según la Iglesia católica, pasar al juicio de Dios y, por tanto, a su destino definitivo (en el cielo o en el infierno) o provisional (purgatorio). Dicho momento siempre es recogido, como hemos visto en párrafos anteriores, como algo cuyo momento de llegar se desconoce, pero siempre como algo inevitable y temible para el ser humano, que procura aliviar pensando en el disfrute futuro y eterno de los goces del paraíso, preparando para ello el camino a través de toda

56 AHMJF, APN, Bartolomé de Maya, fo 63rv., 28 de marzo de 1490: testamento de Juan Peres Peçano (en este caso observamos como se utiliza aún la fórmula objetiva en la redacción del documento "... fase su testamento...", frente a la subjetiva que se impone a partir de 1504 con la pragmática de Alcalá de los Reyes Católicos, en Rojas Vaca, Maㅡ D. 1995. "Notariado público y documento notarial en Jerez de la Frontera en el tránsito a la modernidad", I Jornadas sobre el Notariado en Andalucía: 291-338, Sevilla.

57 AHMJF, APN, oficio 2, Sebastián Gaitán, fo 567v., 9 de septiembre de 1511: testamento del portugués Juan Rodrigues, vecino en Santiago.

58 AHMJF, APN, oficio 3, Rodrigo de Cuenca, fo 175v., 22 de abril de 1521: testamento del veinticuatro Leonís Adornio, corregidor y alcaide de Arcos, vecino en la collación de San Marcos.

59 AHMJF, APN, oficio 8, Gómez Patiño, fo 750v., 17 de septiembre de 1548: testamento del trabajador portugués Juan Martín, vecino en Santiago.

60 AHMJF, APN, oficio 5, Rodrigo de Rus, fo roto v., 12 de septiembre de 1548: Catalina Mendes.

61 AHMJF, APN, oficio 10, Bartolomé Gil de Palencia, fo 1005rv., 16 de septiembre de 1542: testamento del curtidor genovés Pedro Perseva de la Cruz, vecino en el Salvador. una serie de mandas que le faciliten el acceso directo al mismo o, al menos, una estancia lo más corta posible en el purgatorio.

El fallecimiento tiene lugar en multitud de ocasiones en la morada del enfermo aunque, a veces, sea algún hospital (de la Misericordia y de la Sangre son los que hemos documentado en mayor número de casos, aunque alguno también en el de Santa María del Pilar62 o en el de San Blas) ${ }^{63}$ el sitio donde se produce el óbito, ya que registramos el deseo por parte de los enfermos de ser llevados allí en caso de que no se hallen en el mismo. ${ }^{64}$

El entierro constituye el momento culminante de las honras que se han de celebrar para favorecer el camino al paraíso del finado, acto central que conforma la liturgia de la muerte.

Las posibilidades que se ofrecen al testador a la hora de establecer el lugar de su enterramiento son varias, desde las iglesias, pasando por los monasterios y terminando en los hospitales. Veamos en una tabla estadística la distribución de tales lugares en los 116 testamentos (aquí recogemos el total y no los 109 reducidos, pues algún testador cambia de lugar al redactar por segunda vez sus últimas voluntades). Para ello presentamos tres tablas: la primera con la distribución de los enterramientos en iglesias, aunque alguna de ellas como la de San Alifonso nunca llegó a construirse. ${ }^{65} \mathrm{La}$

62 AHMJF, APN, oficio 11, Leonís Álvarez, fo 2050v., 4 de diciembre de 1550: testamento del francés Juan de Ublete, natural de Oyeres (Normandía) y estante en Jerez, quien redacta su testamento en dicho hospital, lugar además en que quiere ser enterrado.

63 En San Blas testa el portugués Françisco Vaes, vecino de Cubillana y estante, quien desea sepultura en la iglesia de San Mateo "en la sepultura que allí tiene el dicho hospital del señor San Blas": AHMJF, APN, oficio 8, Gómez Patiño, fo 984v., 17 de octubre de 1546. La fiesta de San Blas se celebra el día tres de febrero y "ejerció la Medicina y se le considera como uno de los catorce santos auxiliadores. Por ello se le invoca en los conflictos de conciencia por pecados no confesados y contra los males de garganta", Pérez González, S. Ma. 2005: 55. Sobre el Hospital de San Blas sólo hemos recogido una noticia en las Actas Capitulares, fo 238r., 16 de julio de 1533: la Petición de Pedro Camacho de Villavicencio de modificar su casa (en la collación de San Mateo), que alinda con dicho hospital, de manera que necesita un rincón y pared del mismo para dicha obra. Se decide que lo vean dos veinticuatros.

64 AHMJF, APN, oficio 11, Leonís Álvarez, fo 554v., 16 de abril de 1548: la portuguesa Ginebra Luys, mujer de Francisco de Santa María, vecina en Santiago, testa señalando que su cuerpo sea llevado el Hospital de la Sangre "en el qual mando sea llevado antes de mi falleçimiento, para que en el dicho hospital fallesca e sea enterrado en la sepultura que en el dicho hospital me dieren los hermanos dél...".

65 En ella quiso enterrarse doña Clara Marrufo, genovesa casada con el veinticuatro Martín Dávila, quien testa en diciembre de 1541, pues la apertura del testamento por su viudo se realiza en agosto de 1542: AHMJF, APN, oficio 3, Rodrigo de Cuenca, fo 624rv., 29 de agosto de 1542 , donde se señala que testó nueve meses antes. En él mandaba que su cuerpo fuera sepultado en "la yglezia del señor Sant Alifonso desta dicha çibdad, y si aconteçiere que cuando de mí acaeçiere finamiento la dicha yglezia no estuviere no estuviere (sic) acabada de faser, mando y es mi voluntad que mi cuerpo se ponga en depósito en la yglezia del señor San Juan Evangelista, en la capilla de Yñigo Lopes de Carrizosa, mi visagüelo que aya gloria, hasta tanto que la dicha... esté acabada, y luego que estuviere acabada la dicha yglezia traygan mi cuerpo y lo pongan en ella, y se ponga e meta en la parte y lugar de la dicha yglezia de Sant Alifonso que fuese señalado al dicho Martín Dávila, mi marido, para su enterramiento, conforme al testamento del señor Garçía Dávila, veynte e quatro, su padre que aya gloria, y la manera e forma que tengo de ser enterrada remito al dicho Martín Dávila e a mis albaceas, y mando ser enterrada en el ábito de Nuestra Señora de la Merçed". Afirma Sánchez Saus, R. 1988. "De los patrimonios nobiliarios en la Andalucía 
segunda tiene aquellos enterramientos que corresponden a monasterios y hospitales, mientras la tercera es un sumatorio de las dos anteriores añadiendo aquéllos que no indican lugar de enterramiento, los que lo dejan al arbitrio de sus albaceas, y los que no muestran preferencia por iglesia o monasterio determinado, dejando la elección a criterio de sus albaceas.

TABLA ESTADÍSTICA № 1

Enterramientos en iglesias según los testamentos

\begin{tabular}{|l|c|c|c|c|c|}
\hline lugar & S. Alifonso & S. Dionisio & S. Juan & S. Juan Letrán & S. Lucas \\
\hline número & 1 & 2 & 1 & 12 & 4 \\
\hline lugar & S. Marcos & S. Mateo & S. Miguel & El Salvador & Santiago \\
\hline número & 11 & 4 & 9 & 12 & 2 \\
\hline total iglesias & \multicolumn{5}{l}{} \\
\hline
\end{tabular}

TABLA ESTADÍSTICA № 2

Enterramientos en monasterios y hospitales según los testamentos

\begin{tabular}{|l|c|c|c|c|}
\hline lugar & Espíritu Santo & Madre Dios & Merced & San Francisco \\
\hline número & 1 & 1 & 3 & 16 \\
\hline lugar & Santo Domingo & Hospital Misericordia & Hospital Pilar & Hospital Sangre \\
\hline número & 2 & 17 & 1 & 7 \\
\hline \multicolumn{4}{|l}{ total monasterios y hospitales } \\
\hline
\end{tabular}

TABLA ESTADÍSTICA № 3

Enterramientos de los extranjeros en Jerez según sus testamentos

\begin{tabular}{|c|c|c|c|c|c|c|}
\hline lugar & iglesias & $\begin{array}{c}\text { monasterios } \\
\text { y hospitales }\end{array}$ & $\begin{array}{c}\text { iglesia o } \\
\text { monasterio }\end{array}$ & $\begin{array}{c}\text { iglesia sin } \\
\text { especificar }\end{array}$ & $\begin{array}{c}\text { donde digan } \\
\text { albaceas }\end{array}$ & $\begin{array}{c}\text { sin } \\
\text { indicar }\end{array}$ \\
\hline número & 58 & 48 & 1 & 2 & 2 & 5 \\
\hline total
\end{tabular}

del siglo xv. Los bienes del caballero jerezano Martín Dávila (1502)", Anuario de Estudios Medievales 18: 469-485, en p. 472, que el caballero Martín Dávila, ascendiente del citado, "habitó las casas de la plazuela de San Ildefonso. Tan grande llegó a ser la hegemonía de los Dávila en este barrio que Martín consiguió fuese declarado nueva collación en 1480, extraída de la de San Salvador, siendo su jurado mientras duró la novedad. La capilla de San Ildefonso era entierro perpetuo, pila y sagrario privativo de los caballeros de su linaje". Sobre dicha iglesia registramos en 1539 en capitulares la petición al concejo de Martín Dávila Sigüenza de una calleja para hacer la iglesia de San Alifonso, de acuerdo con la última voluntad de su padre García Dávila. Se decide remitirlo a dos caballeros diputados del regimiento: AHMJF, AC, fo 719v., 20 de agosto de 1539. Garçía Dávila testó también ante Rodrigo de Cuenca, fo 197rv, 14 de febrero de 1538, ordenando ser enterrado junto a su mujer (doña Ysabel de Melgarejo) "anbos en la yglesia del señor sant Alifonso, que es junto e çerca de las casas de nuestra morada... mando... junto al pie del altar de la dicha yglesia se hagan dos cañones: el vno para el enterramiento mío e de la dicha doña Ysabel... e otro para el enterramiento de Martín de Ávila, mi hijo...".
Observamos por los datos anteriores que superan en número aquéllos que prefieren ser enterrados en iglesias (58 más dos que no especifican el nombre de la iglesia son 60 casos) a los que prefieren hacerlo en hospitales (25) o monasterios (23). Entre las iglesias está clara la primacía de las de El Salvador, San Juan de Letrán (en la collación de Santiago), San Marcos y San Miguel, con cantidades muy pequeñas en el resto. En El Salvador quieren enterrarse once genoveses y un flamenco, todos moradores de dicha collación, excepto uno que vive en San Dionisio, otro que es estante y un tercero que no declara la parroquia donde habita. Por su parte en San Juan de Letrán prefieren hacerlo cinco franceses, cinco portugueses y dos genoveses; de ellos seis son estantes, cinco habitan en la collación de San Miguel y otro en San Dionisio. Por su parte los once de San Marcos se distribuyen entre nueve genoveses y dos portugueses; cinco son parroquianos de dicha iglesia, dos habitan en San Juan, uno en San Lucas, uno en Santiago, uno en San Salvador y el último es un estante (transeúnte, en terminología actual). En la iglesia de San Miguel quieren ser enterrados dos genoveses, seis portugueses y un francés, que se distribuyen entre dicha collación (seis casos) y tres que son estantes en la ciudad.

Entre los hospitales es el de la Santa Misericordia (en la collación de San Dionisio) quien ocupa la predilección (los 17 casos están representados por testadores portugueses, todos estantes en Jerez).

Hemos de añadir que en estos casos se da además la circunstancia de nombrar como albaceas a los hermanos mayores o al capellán del Hospital de la Misericordia, como ocurre a Gomes Fernandes, natural del lugar de Belesar de Meles, vecino de Porto y estante, quien testa en 1545 en dicho Hospital, nombra heredero a esta institución y al clérigo presbítero Pedro de Hinojosa, capellán del mismo, como su albacea. ${ }^{66}$

En algún caso lo que hace el testador es dividir su herencia: sus bienes en Portugal para algún familiar, mientras los que posee en Castilla los dona al citado hospital, v.g. el que realiza Juan Fernandes "portugués natural del lugar de Peñalua que es junto a San Juan que es en el reyno de Portugal...", 67 quien ordena que todos sus bienes y deudas que le deben en los reinos de Castilla sean para el hospital citado y los que tiene en Portugal sean para su hermano Antonio Pérez, a quien deja como heredero.

Hallamos algún testador que mantiene relaciones laborales con dicho Hospital como muñidor del mismo y de la cofradía correspondiente, y que se halla en la enfermería del mismo en el momento de testar, reconociendo incluso que la institución le adeuda cierta cantidad "confieso que el dicho Hospital e los hermanos e cofrades dél en su nonbre me deven çierto serviçio que en él he hecho lo qual remito al

66 AHMJF, APN, oficio 5, Rodrigo de Rus, fo ileg. v., 12 de enero de 1545: En unas de las mandas señala que no le pidan cuenta a su hermano Bartolomé Opolo del tiempo que ha tenido su hacienda "porque yo le fago graçia e suelta de todo lo que él me deve hasta oy en cualquier manera de quentas que entre nos a avido, eçebto las heredades e bienes que declarados tengo, que éstos mando e quiero e es my voluntad que los aya e los herede el dicho Hospital de la Santa Misericordia desta çibdad de Xerez e la hermandad e cofradía dél para los gastos que hazen con los pobres e extranjeros e enfermos que a él se acojen".

67 AHMJF, APN, oficio 5, Rodrigo de Rus, fo 273rv., 1 de abril de 1536 
libro del dicho Hospital". Se trata de Juan Martín, portugués estante, quien nombra heredero al dicho hospital y albaceas a los hermanos mayores del mismo Gonçalo Gomes de la Romana y Alonso Guarnido. ${ }^{68}$

Con un número también destacado de testadores aparece el hospital de la Sangre (situado en la parroquia de Santiago, donde quieren recibir sepultura seis portugueses -tres estantes y tres que moran en dicha collación-, y un genovés vecino en dicha parroquia), mientras que el Monasterio de San Francisco representa lo propio entre los cenobios (aquí existe una mayor dispersión en cuanto a nacionalidades, pues hallamos seis portugueses -hemos incluido al novicio franciscano, pues, aunque no declare de manera expresa su intención de ser enterrado en dicho monasterio, al tratarse de un franciscano parece razonable adjudicarle como lugar de enterramiento dicho convento-, siete genoveses, un francés, un aragonés y un flamenco, así como la distribución por el entramado urbano, ya que se trata de seis estantes y once vecinos, de los cuales cuatro viven en San Miguel -parroquia donde se hallaba dicho monasterio-, dos en Santiago, dos en el Salvador, uno en San Marcos y otro en San Lucas).

Proponemos a continuación un nuevo cuadro donde recogemos el lugar del entierro que se deja a criterio de los albaceas, así como el nombre de éstos y la relación que unía al testador con quien debía cumplir su voluntad.

TABLA ESTADÍSTICA № 4

Testadores que dejan a criterio de sus albaceas lugar de su entierro

\begin{tabular}{|l|l|l|l|}
\hline \multicolumn{1}{|c|}{$\begin{array}{c}\text { reseña } \\
\text { documental }\end{array}$} & \multicolumn{1}{|c|}{ nombre } & \multicolumn{1}{|c|}{$\begin{array}{c}\text { a criterio de } \\
\text { los albaceas }\end{array}$} & \multicolumn{1}{c|}{ albaceas } \\
\hline $\begin{array}{l}\text { 1521, oficio 7, } \\
\text { fo 1228rv. }\end{array}$ & $\begin{array}{l}\text { Da Ysabel de } \\
\text { Espíndola }\end{array}$ & sepultura & $\begin{array}{l}\text { Su marido: Yñigo } \\
\text { Lopes de Carrizosa }\end{array}$ \\
\hline $\begin{array}{l}\text { 1539, oficio 5, } \\
\text { fo roto rv. }\end{array}$ & Juan Laboria & Iglesia de Jerez & $\begin{array}{l}\text { Juan Bastardo y Juan } \\
\text { Cayrana, caldereros }\end{array}$ \\
\hline $\begin{array}{l}\text { 1540, oficio 7, } \\
\text { fo 147rv. }\end{array}$ & María de Acosta & Iglesia de Jerez & $\begin{array}{l}\text { Bartolomé Nuñes de } \\
\text { Villaviçençio, en cuya casa vive }\end{array}$ \\
\hline $\begin{array}{l}\text { 1540, oficio 7, } \\
\text { fo 107rv. }\end{array}$ & Batistina Marques & $\begin{array}{l}\text { Iglesia o monasterio } \\
\text { de Jerez }\end{array}$ & $\begin{array}{l}\text { Su hermano } \\
\text { Antono Marques }\end{array}$ \\
\hline $\begin{array}{l}\text { 1548, oficio 10, } \\
\text { fo 591rv. }\end{array}$ & Álvaro Figueira & $\begin{array}{l}\text { Iglesia o monasterio } \\
\text { de Jerez }\end{array}$ & $\begin{array}{l}\text { Su hija Juana } \\
\text { Hernandes y Diego Martín } \\
\text { de Estorga el viejo }\end{array}$ \\
\hline
\end{tabular}

El lugar del entierro también nos ayuda a conocer la calidad de las relaciones entre distintos grados de parentesco. Así hallamos quienes quieren ser enterrados junto a sobrinos (v.g. el calderero francés Juan Bastardo, vecino en San Miguel, quiere sepultura en la iglesia de San Juan de Letrán "en la sepultura que está enterrado Mondote, françés, mi sobrino"); ${ }^{69}$ tíos (caso de Guillermo Conde de Gave quien manda ser enterrado en El Salvador en la sepultura que tiene su tío Pedro Perseva de la Cruz); ${ }^{70}$

\footnotetext{
68 AHMJF, APN, oficio 5, Rodrigo de Rus, fo 405v., 12 de abril de 1540.

69 AHMJF, APN, oficio 5, Rodrigo de Rus, fo 290v., 9 de marzo de 1540.

70 AHMJF, APN, oficio 5, Rodrigo de Rus, fo 290rv., 25 de marzo de 1546.
}

junto a su marido (caso de Clara Marrufo, la cual quiere que la entierren de manera provisional en San Juan de los Caballeros, en la capilla de su bisabuelo, ${ }^{71}$ y de manera definitiva en San Ildefonso junto a su marido:); ${ }^{72}$ junto a su esposa (caso del atahonero portugués Peri Anes, quien desea enterrarse en la iglesia de San Lucas -parroquia de la que es vecino- "en la sepultura donde está enterrada María Franca, mi muger, e Juan, my hijo, que sean en gloria"), ${ }^{73}$ o alguno de los padres (caso del genovés Juan Ginovés, hijo de Niculás Martín, albañil difunto, quien desea sepultura en la iglesia de El Salvador donde está enterrado su padre). ${ }^{74}$

En cuanto a la cantidad que se debía satisfacer en concepto de abrimiento de sepultura a veces se declara de manera expresa (como hace Catalina de Figueroa, viuda del jurado Françisco Adorno, quien manda ser enterrada en la iglesia de San Marcos, ordenando se entreguen veinte maravedís por el abrimiento: "en sepultura e capilla que yo tengo donde está enterrado el dicho jurado Françisco Adorno, mi marido"),${ }^{75}$ y en la mayoría de las ocasiones se utiliza la consabida fórmula de que se dé la costumbre. $^{76}$

En otros casos lo que se ordena es simplemente que se compre por sus albaceas una sepultura donde enterrarse, como hace el odrero genovés Antono Marques en 1543: quiere ser enterrado en San Marcos "e me compren vna sepultura que quede para mis hijos e sucesores...".77

Como mortajas, lo usual era ser enterrado con la sábana o sudario con que se envolvía el cuerpo del difunto. En algunos casos los moribundos preferían ser enterrados vestidos con el hábito de una orden religiosa determinada, pues estimaban que de esta forma se les facilitaba aún más la entrada en el paraíso.

Sólo hemos documentado diez personajes que declaren en su testamento su deseo de ser amortajados con el hábito de alguna orden. Se distribuyen entre siete que optan por

71 Es el concepto de "fosa agnática" que recoge Jaime Piqueras, J. 2012: 244: "... debería tratarse de los padres, abuelos e hijos de los testadores, cuando la realidad, tal y como manifiestan los propios interesados en sus testamentos es que en esas fosas se encontraban los consanguíneos con antepasado común, no sólo padres o abuelos, sino una gran variedad de parientes con el denominador común que la organización patrilineal de la familia extensa impone".

72 AHMJF, APN, oficio 3, Rodrigo de Cuenca, fo 624rv., 29 de agosto de 1542: "la yglezia del señor Sant Alifonso desta dicha çibdad, y si aconteçiere que cuando de mí acaeçiere finamiento la dicha yglezia no estuviere no estuviere (sic) acabada de faser, mando y es mi voluntad que mi cuerpo se ponga en depósito en la yglezia del señor San Juan Evangelista, en la capilla de Yñigo Lopes de Carrizosa, mi visagüelo que aya gloria, hasta tanto que la dicha... esté acabada, y luego que estuviere acabada la dicha yglezia traygan mi cuerpo y lo pongan en ella, y se ponga e meta en la parte y lugar de la dicha yglezia de Sant Alifonso que fuese señalado al dicho Martín Dávila, mi marido, para su enterramiento...".

73 AHMJF, APN, oficio 5, Rodrigo de Rus, fo 701rv., 30 de julio de 1545.

74 AHMJF, APN, oficio 18, Simón García Copín, fo 166v., 13 de marzo de 1549.

75 AHMJF, APN, oficio 2, Sebastián Gaitán, fo 588rv., 3 de agosto de 1506.

76 AHMJF, APN, oficio 18, Simón García Copín, fo 166v., 13 de marzo de 1549: Juan Ginovés quiere ser enterrado en la iglesia de San Miguel, en el sitio donde está sepultado su padre y manda que "e por el abrimiento se pague de mis bienes la limosna acostunbrada".

77 AHMJF, APN, oficio 7, Luis de Llanos, fo 477rv., 19 de junio de 1543. 
el hábito franciscano y uno con el de la Merced, otra de la Victoria y el último con el de la Cofradía del Nombre de Jesús.

Observamos que sólo están representadas tres órdenes (franciscanos, mercedarios y jerónimos), más una hermandad (el Nombre de Jesús, relacionada, eso sí, con la Orden dominicana, pues su sede definitiva será el Convento de Santo Domingo de la ciudad). En segundo lugar, el escaso número que declaran querer ser amortajados con algún hábito (sólo diez de 116 casos, aproximadamente el nueve por ciento). En tercer lugar es resaltable la primacía de los que prefieren el hábito franciscano (siete de diez, o sea, un setenta por ciento de los que declaran tal deseo o, si se prefiere, un seis por ciento del total de testadores). Ello nos estaría indicando el predicamento que en la sociedad de la época tenían las enseñanzas de san Francisco, creemos que en especial la cuestión de la pobreza que podemos relacionar con el pasaje evangélico del joven rico. ${ }^{78}$ Los demás tienen una representación testimonial: uno para Nuestra Señora de la Merced, otro para Nuestra Señora de la Victoria, y un último para la recientemente creada Cofradía del Nombre de Jesús de los genoveses (fundada en 1546). ${ }^{79}$

¿Quiénes son los personajes que quieren ser enterrados con el hábito franciscano? Pues hallamos un calderero francés (Juan Lopes: "e que se pague en limosna su valor de mis bienes"), ${ }^{80}$ vecino en San Miguel; cuatro portugueses (el novicio franciscano Benito Restrojo, vecino de Olivenza y estante; ${ }^{81}$ Juan Fernandes, vecino de Lisboa y estante: “... y que antes que yo sea fallecido se me vista vn ábito del señor San Françisco e se dé otro nuevo al dicho monesterio"; 82 Catalina Mendes, esposa del mercader Rodrigo Álvares, vecina en San Miguel: entierro en el monasterio de San Francisco "e en el ábito de la dicha Horden"; 83 Juan Rodrigues, vecino en Santiago), ${ }^{84}$ y dos genoveses (Angelina Casana, mujer del curtidor Bartolomé Casán, vecina en San Salvador, ${ }^{85}$ y el curtidor Antono de Hinojos, vecino en San Lucas). ${ }^{86}$

Doña Clara Marrufo, genovesa casada con el veinticuatro Martín Dávila Sigüenza, vecina en El Salvador, es la que prefiere ser enterrada con el hábito mercedario: “...mando ser enterrada en el ábito de Nuestra Señora de la Merçed"; 87 mientras el odrero genovés Antono Marques, vecino en San

\footnotetext{
78 Mateo 19, 16-22.

79 Mingorance Ruiz, J. A. 2012. “Aportación documental a la historia de la Cofradía del Nombre de Jesús de Jerez de la Frontera", Religiosidad sevillana. Homenaje al profesor José Sánchez Herrero: 339-365. Sevilla. 1547.

80 AHMJF, APN, oficio 5, Rodrigo de Rus, fo 241rv., 9 de marzo de

81 AHMJF, APN, oficio 5, Rodrigo de Rus, fo 1073rv., 17 de agosto de 1539 .

82 AHMJF, APN, oficio 8, Francisco del Mercado, fo 485rv., 1 de septiembre de 1528.

83 AHMJF, APN, oficio 5, Rodrigo de Rus, fo roto v., 12 de septiembre de 1538.

84 AHMJF, APN, oficio 2, Sebastián Gaitán, fo $567 v ., 9$ de septiembre de 1511.

${ }_{85}$ AHMJF, APN, oficio 5, Rodrigo de Rus, fo 461rv., 7 de abril de 1539.

86 AHMJF, APN, oficio 3, Rodrigo de Cuenca, fo 847rv., 14 de septiembre de 1541.

87 AHMJF, APN, oficio 3, Rodrigo de Cuenca, fo 624rv., 29 de agosto de 1542 .
}

Marcos, prefiere el hábito de Nuestra Señora de la Victoria: "Yten mando que me entierren en el ábito de Nuestra Señora de la Vitoria, que se lo pidan a los frayles e confesor de las monjas desta çibdad" y den la costumbre;8 y el tonelero Lorenço Panel, vecino en San Miguel, que lo amortajen con el hábito de la Cofradía del Nombre de Jesús: "y me entierren en el ábito de mi Cofradía de los ginoveses donde soy hermano". 89

En ninguno de los casos que hemos registrado se declara cantidad alguna para pagar a la orden con cuyo hábito se desea ser enterrado.

Suponemos que la mayoría de los entierros debieron ser bastante simples, exentos de una gran parafernalia, salvo la cuestión de que se ofreciese al menos una misa por el alma del fallecido. Por ello son muy escasos los testamentos en que no se desee realizar como mínimo una misa de réquiem, salvo los casos del portugués Hernando de Espino, vecino de Puerto Real y estante ${ }^{90}$ y el de su compatriota Pedro Martín, vecino de Quintanilla y estante, quien declara sobre el lugar de su entierro en la Misericordia "donde yo al presente estoy enfermo, en la sepoltura donde se entierran los pobres". ${ }^{11}$

Luego tenemos la cuestión de luto como señal de duelo de familiares por la pérdida del ser querido. Debió ser costumbre extendida el llevar luto por los familiares muertos, lo que denotaría ese gusto por parte de la generalidad de los testadores. En un testamento documentamos la existencia de tales prendas: en 1548 la portuguesa Ginebra Luys, esposa del trabajador Françisco de Santa María, vecina en Santiago, declara que posee una saya, un mantillo de luto y otros bienes. ${ }^{92}$

Pero también hallamos algún caso de personas que prefieren que no les guarden luto, incluso amenazan con su maldición si se intenta llevarlo, aduciendo que lo que valen son las plegarias por el alma del difunto. ${ }^{93}$

88 AHMJF, APN, oficio 7, Luis de Llanos, fo 477rv., 19 de junio de 1543.

89 AHMJF, APN, oficio 11, Leonís Álvarez, fo 825v., 11 de junio de 1546.

90 AHMJF, APN, oficio 4, Juan Rodríguez, fo 897rv., 23 de octubre de 1524.

91 AHMJF, APN, oficio 12, Martín de la Cruz, fo 428rv., 11 de mayo de 1547.

92 AHMJF, APN, oficio 11, Leonís Álvarez, fo 554v., 16 de abril de 1548

93 AHMJF, APN, oficio 7, Luis de Llanos, fo 163rv., 22 de febrero de 1538, y oficio 1, Francisco Román de Trujillo, fo 310rv. y 311r., 5 de junio de 1545: el veinticuatro genovés Francisco Adorno, vecino en San Lucas, en 1538 declara que "Ia dicha doña Ana, mi muger, ni mis hijos, ni criados, ni parientes, por mí no se pongan ni vistan luto ninguno, ni se haga sentimiento alguno; en lugar del dicho luto e sentimiento les ruego e pido y encargo que rueguen a Dios nuestro Señor por mi ánima la quiera encaminar e llevar a su santa gloria para donde fue criada..."; cuestión que reitera en la nueva redacción de sus últimas voluntades en 1545 -incluyendo la amenaza de maldecir a quienes incumplan su deseo-, al decir: "Ytem más mando, so pena de mi maldición, a mis hijos y criados y así lo suplico a mis albaçeas que lo hagan mantener y guardar, que nadie saque luto ni se ponga por mí ni lo trayga día ninguno, porque ésta es mi determinada voluntad". Lo mismo había ordenado su padre, el también veinticuatro Leonís Adorno, en oficio 3, Rodrigo de Cuenca, fo 175v., 22 de abril de 1521. 


\section{El funeral}

El funeral o cortejo funerario constituye una de las preocupaciones básicas del testador: qué clérigos, cofradías y hermandades habían de acompañar su cadáver, quiénes, dónde (iglesias y/o monasterios) y cuántas misas de réquiem (rezadas o cantadas, ofrendadas de pan, vino y cera), si dichos clérigos habían de salir sobre su sepultura a decir oración y responso, la cantidad a abonar en concepto de dichas honras, etc., todo ello queda perfectamente establecido en la declaración de últimas voluntades del testador.

Encontramos una gran cantidad de posibilidades a la hora de configurar el cortejo fúnebre: clérigos y capellanes de iglesias, hermandades y cofradías, presencia o no de cruz, etc. Vamos a recoger en unas tablas los resultados (por orden alfabético de nombres) que hemos obtenido de analizar los datos de todos los testamentos documentados; una primera referida a las iglesias y la siguiente con los datos correspondientes a hermandades, cofradías y monasterios.

TABLA ESTADÍSTICA № 5

Iglesias cuyos curas y capellanes han de formar parte de los cortejos fúnebres ${ }^{94}$

\begin{tabular}{|l|c|c|c|c|c|}
\hline iglesia & San Dionisio & San Juan & $\begin{array}{c}\text { San Juan } \\
\text { de Letrán }\end{array}$ & San Lucas & San Marcos \\
\hline número & 10 & 2 & 1 & 3 & 10 \\
\hline iglesia & San Mateo & San Miguel & El Salvador & Santiago & \\
\hline número & 1 & 22 & 14 & 8 & 71 \\
\hline total
\end{tabular}

Observamos como una clara mayoría prefiere ser acompañado por los clérigos de la iglesia de San Miguel, apareciendo a cierta distancia los de la Colegial de El Salvador y a un nivel inferior los de las iglesias de San Marcos, San Dionisio y Santiago, y cantidades simbólicas del resto. La explicación creemos que puede venir del hecho de tratarse de la iglesia sita en la collación más poblada de la ciudad en el siglo XVI, así como estar ubicada asimismo en ella los dos monasterios de Santo Domingo y San Francisco. El caso de la Colegial se puede explicar en función de ser la collación con mayor concentración de genoveses de toda la ciudad.

94 De San Dionisio hay dos que además de sus curas correspondientes quieren que les acompañen los clérigos con la cruz; de San Juan, uno con la cruz y otro con capellanes; de San Lucas, uno con la cruz y otro con capellanes; de San Marcos, uno con la cruz; de San Miguel, dos con la cruz y uno con capellanes; de El Salvador, uno con la cruz y cuatro con capellanes, y de Santiago, uno con diez capellanes. A estos 71 casos hay que añadir uno que manifiesta que los curas que diga su marido; otro quienes digan sus hijos; otro quienes digan sus albaceas, y 35 que no manifiestan dicha cuestión.
TABLA ESTADÍSTICA № 6

Hermandades, cofradías y monasterios que han de conformar los cortejos fúnebres ${ }^{95}$

\begin{tabular}{|l|c|c|c|c|}
\hline hermandad & Hospital Sangre & $\begin{array}{c}\text { Limpia } \\
\text { Concepción }\end{array}$ & Misericordia & Niños doctrina \\
\hline número & 9 & 10 & 25 & 1 \\
\hline hermandad & Nombre de Jesús & Ntra Sra Piedad & Ntra Sra Pilar & $\begin{array}{c}\text { Ntra Sra } \\
\text { Remedios }\end{array}$ \\
\hline número & 5 & 1 & 2 & 1 \\
\hline hermandad & Ntra Sra Rosario & San Bartolomé & San Blas & San Juan Letrán \\
\hline número & 15 & 12 & 1 & 12 \\
\hline hermandad & San Sebastián & Sto Domingo & Sto Sacramento & Veracruz \\
\hline número & 2 & 1 & 4 & 7 \\
\hline total & \multicolumn{2}{|c}{} & & 107 \\
\hline
\end{tabular}

Entre las hermandades queda clara la primacía de la Misericordia, seguida por Nuestra Señora del Rosario, San Bartolomé, San Juan de Letrán, la Concepción y la Sangre. Creemos poder explicar dicha primacía en función de la gran cantidad de portugueses estantes en la ciudad que acuden al Hospital de la Santa Misericordia y allí redactan su testamento, como hemos apuntado con anterioridad. El caso de la Hermandad del Rosario ${ }^{96}$ tiene una gran frecuencia, pues se hallaba en el Convento de Santo Domingo, sito en una zona comprendida en la collación de San Miguel (su parte baja), pero asimismo muy cerca de la de San Marcos y de parte de la de Santiago, lo que la hacía muy próxima a testadores de tales distritos. La de San Juan de Letrán no sabemos si se asimila a la de San Sebastián, como afirman algunos autores. ${ }^{97}$

En cuanto a la Cofradía de la Concepción parece que la devoción entre los jerezanos en general, y entre los extranjeros residentes en la ciudad, a la Inmaculada estaba muy extendido y se remonta "al menos, hasta el siglo xv y desde un principio estuvo muy vinculada a la orden franciscana, como un reflejo local de lo que sucedió en España desde fines de la Edad Media". ${ }^{98}$ El resto (San Blas, Santo Domingo,

95 En la Hermandad del Rosario hay uno que manifiesta su deseo que le acompañen con su cruz e insignias; el caso del monasterio dominico pertenece a un personaje que quiere ser acompañado por doce frailes de dicho convento a imitación de los doce apóstoles. A estos 107 casos hay que añadir uno que lo deja a arbitrio de sus hijos y cinco a la voluntad de sus albaceas.

96 Romero Mensaque, C. J. 2012. "Un estado de la cuestión sobre el Rosario y sus cofradías en España”, en Religiosidad sevillana...: 178-179: “... la fundación de la primera Cofradía en Colonia el 8 de septiembre de 1475... No era una ciertamente una hermandad mariana más,... sino que,... hay una intención consciente de buscar una nueva orientación en la línea de la devotio moderna... Esto hay que relacionarlo con las inquietudes de prerreforma en busca de una comunicación sencilla y directa con Dios... En este sentido, la Orden de Predicadores consiguió un gran éxito al conectar con esta ansia de reforma de la población".

97 Pomar Rodil, P. J. y Mariscal Rodríguez, M. Á. 2004. Jerez de la Frontera. Guía artística y monumental, Jerez, Sílex Ediciones, en p. 43, señala que la fundación de la capilla de San Juan de Letrán se hizo en 1504 "con el ánimo de constituir en ella una colegiata exenta dependiente del Cabildo de la catedral de Roma, pronto quedaría reducida a una modesta capilla con pila bautismal, de la que cuidaban los cofrades del antiguo hospital de San Sebastián".

98 Romero Bejarano, M. 2005. "La construcción de la capilla de la Limpia Concepción del monasterio de San Francisco de Jerez de la 
Nuestra Señora de los Remedios, etc.) presenta frecuencias muy poco significativas.

La Hermandad de Nuestra Señora de los Remedios tenía su capilla y hospital en la Puerta del Real, y “... en este lugar junto a la Puerta Real, ya existía desde poco después de la Reconquista de la ciudad, una pequeña capilla dedicada a la Virgen, quien según la leyenda habría prestado ayuda a los caballeros jerezanos en la batalla de los Cueros". Actualmente lo que se conserva es su portada del siglo XVII. ${ }^{99}$

¿Qué cantidades se abonan en concepto de acompañamiento del cadáver? Lo usual es decir que se abone lo acostumbrado. ${ }^{100}$ Pero en algunos casos se declara explícitamente dicho importe. ${ }^{101}$

\section{Los oficios de difuntos}

El día del entierro el principal oficio está constituido por la misa de réquiem en sus variantes de rezada y cantada (más solemne y más cara obviamente). A ella se pueden añadir otras misas rezadas, así como salir sobre la sepultura. Vamos a reflejar en una nueva tabla los datos obtenidos con el análisis de este aspecto de los testamentos redactados por extranjeros.

TABLA ESTADÍSTICA № 7

Tipología de los oficios de difuntos el día del entierro. ${ }^{102}$

\begin{tabular}{|l|c|c|c|c|}
\hline tipo & rezada & cantada & $\begin{array}{c}\text { las que digan los } \\
\text { albaceas }\end{array}$ & sin indicar \\
\hline número & 150 & 102 & 7 & 20 \\
\hline total & & 279 \\
\hline
\end{tabular}

Comprobamos a partir de los datos anteriores que lo usual era ordenar una misa rezada por el alma del difunto y parece razonable, pues ordenar la celebración de misas cantadas (y más si eran ofrendadas de pan, vino y cera) no resultaba al alcance de cualquier economía.

Frontera", Actas del Simposium La Inmaculada Concepción en España: religiosidad, historia y arte: 1007-1029, citando a López Fé y Figueroa, C. M. 2004. "Sine labe concepta. De una piadosa creencia al Dogma", Inmaculada. 150 Años de la proclamación del Dogma: 41-69, Córdoba.

99 Pomar Rodil, P. J. y Mariscal Rodríguez, M. Á. 2004: 113.

100 AHMJF, APN, oficio 10, Bartolomé Gil de Palencia, fo 663v., 17 de septiembre de 1544: el portugués Juan Alonso, vecino de Miranda y estante, manda ser enterrado en el monasterio de la Madre de Dios "en la yglesia nueva que agora se haze", y le acompañen los clérigos de San Miguel y los hermanos de la Concepción de San Francisco y se dé la costumbre.

101 AHJMJF, APN, oficio 7, Luis de Llanos, fo 320rv., 30 de noviembre de 1546: el flamenco Antono de Prinçe, vecino de Amberes y "estante e residente... en... Xeres de la Frontera", manda al Hospital de la Misericordia cuatro ducados para que sus cofrades y hermanos acompañen su cuerpo el día del entierro.

102 El número de misas rezadas es mayor del reflejado, ya que en la manda correspondiente sólo aparece que cada capellán que acompañe el cortejo dé una misa rezada, así que, al desconocer el número de capellanes, no podemos saber con exactitud el número de misas rezadas que, además de la cantada, quería se dijese por su alma. Algunas cantadas son al mismo tiempo ofrendadas de pan, vino y cera. Al número total (279) hay que añadir nueve casos en que se especifica que además salgan sobre la sepultura a decir responso y oración, y dos de ellos expresan su deseo de que dicha salida sobre la sepultura se realice con la cruz y el agua bendita.

\section{Honras fúnebres}

Una vez realizado el entierro del finado se abría un período más o menos largo durante el cual se seguían realizando honras fúnebres por el alma del fallecido, que consistían en novenarios, cabo de novenarios, año y cabo de año, remembranzas, capellanías, etc. Algunas de ellas, tales como las remembranzas o la institución de capellanías tenían el aspecto de intemporales, ya que se hacían a perpetuidad, ordenando usualmente el pago de tales oficios mediante la adscripción de un determinado censo o tributo sobre un bien perteneciente al muerto.

Novenarios. Contabilizamos un total de veintiséis mandas de novenarios por el alma del difunto que han de celebrarse en las siguientes iglesias y monasterios u hospitales.

TABLA ESTADÍSTICA № 8 Lugar de celebración de los novenarios

\begin{tabular}{|c|c|c|c|c|}
\hline institución & Madre de Dios & San Dionisio & San Francisco & $\begin{array}{l}\text { San Juan de } \\
\text { Letrán }\end{array}$ \\
\hline número & 1 & 1 & 5 & 1 \\
\hline $\begin{array}{l}\text { reseña } \\
\text { documental }\end{array}$ & $\begin{array}{l}\text { 1544, oficio } 10 \text {, } \\
\text { fo } 663 \mathrm{v} \text {. }\end{array}$ & $\begin{array}{l}\text { 1537, oficio 6, } \\
\text { fo } 271 \mathrm{v} \text {. }\end{array}$ & $\begin{array}{l}\text { 1541, oficio 3, } \\
\text { fo 847rv.; } \\
\text { 1543, oficio 8, } \\
\text { fo 890rv.; } \\
\text { 1544, oficio 8, } \\
\text { fo 592rv.; } \\
\text { 1544, oficio 10, } \\
\text { fo 663v.; } \\
\text { 1547, oficio 5, } \\
\text { fo } 241 \text { rv. }\end{array}$ & $\begin{array}{l}\text { 1532, oficio 10, } \\
\text { fo 910v. }\end{array}$ \\
\hline institución & San Lucas & San Marcos & San Mateo & San Miguel \\
\hline número & 2 & 2 & 2 & 1 \\
\hline $\begin{array}{l}\text { reseña } \\
\text { documental }\end{array}$ & $\begin{array}{l}\text { 1537, oficio 2, } \\
\text { fo } 728 \text { r.; } \\
\text { 1545, oficio 8, } \\
\text { fo } 682 \text { rv. }\end{array}$ & $\begin{array}{l}\text { 1490, Bartolomé } \\
\text { de Maya, } \\
\text { fo 63rv.; } 1535 \text {, } \\
\text { oficio 6, } \\
\text { fo 891rv. }\end{array}$ & $\begin{array}{l}\text { 1537, oficio 6, } \\
\text { fo } 884 \text { rv.; } \\
\text { 1546, oficio 8, } \\
\text { fo } 292 \text { rv. }\end{array}$ & $\begin{array}{l}\text { 1523, oficio 1, } \\
\text { fo } 32 \mathrm{v} \text {. }\end{array}$ \\
\hline institución & El Salvador & Hospital Sangre & Santiago & \\
\hline número & 5 & 3 & 3 & \\
\hline $\begin{array}{l}\text { reseña } \\
\text { documental }\end{array}$ & $\begin{array}{l}\text { 1527, oficio 8, } \\
\text { fo 565rv.; } \\
\text { 1542, oficio 5, } \\
\text { fo 1031rv.; } \\
\text { 1542, oficio 10, } \\
\text { fo 1005rv.; } \\
\text { 1546, oficio 5, } \\
\text { fo 290rv.; } \\
\text { 1550, oficio 5, } \\
\text { fo ileg. v. }\end{array}$ & $\begin{array}{l}\text { 1538, oficio 2, } \\
\text { fo 529rv.; } \\
\text { 1548, oficio 8, } \\
\text { fo } 750 \mathrm{v} \text {;; } \\
\text { 1548, oficio } 7 \text {, } \\
\text { fo } 237 \mathrm{v} \text {. }\end{array}$ & $\begin{array}{l}\text { 1536, oficio 7, } \\
\text { fo 359v.; } \\
\text { 1537, oficio 3, } \\
\text { fo 416v.; } \\
\text { 1543, oficio 8, } \\
\text { fo 519v. }\end{array}$ & \\
\hline \multicolumn{4}{|l|}{ total } & 26 \\
\hline
\end{tabular}

El reparto por collaciones e iglesias de los novenarios anteriores es el siguiente: los cinco de El Salvador son vecinos de dicha parroquia y quieren enterrarse en la iglesia citada; los cinco de San Francisco se distribuyen entre dos que viven en San Lucas, uno en San Miguel, uno en Santiago y un estante, y todos tienen sepultura en dicho monasterio; los dos de San Mateo corresponden a su collación y sepultura en dicha iglesia, al igual que San Lucas; el del Monasterio de Madre de Dios es estante en la ciudad y quiere sepultura en dicho Convento; los tres del Hospital de la Sangre corresponden dos a Santiago y otro es estante, y todos quieren sepultura 
en dicho Hospital; los tres de Santiago habitan dos dicha collación y uno en San Marcos, y quieren enterrarse uno en dicha iglesia, otro en el Hospital de la Sangre y el tercero en el Monasterio de la Merced y, por último, el de San Juan de Letrán es un estante que quiere sepultura en dicha iglesia.

Sólo hemos hallado trece casos en que, además del novenario, se demande la realización de la misa de cabo de novenario. Los lugares de celebración aparecen reflejados en la tabla que sigue.

TABLA ESTADÍSTICA № 9

Lugar de celebración de los cabos de novenarios

\begin{tabular}{|c|c|c|c|c|}
\hline institución & San Dionisio & San Francisco & San Lucas & San Marcos \\
\hline número & 1 & 3 & 2 & 1 \\
\hline $\begin{array}{l}\text { reseña } \\
\text { documental }\end{array}$ & $\begin{array}{l}\text { 1537, oficio 6, } \\
\text { fo } 271 \mathrm{v} \text {. }\end{array}$ & $\begin{array}{l}\text { 1541, oficio 3, } \\
\text { fo 847rv.; } \\
\text { 1543, oficio 8, } \\
\text { fo 890rv.; 1544, } \\
\text { oficio 8, fo 592rv. }\end{array}$ & $\begin{array}{l}\text { 1537, oficio 2, } \\
\text { fo } 728 \text { r.; } 1545 \text {, } \\
\text { oficio } 8, \text { fo } \\
682 \text { rv. }\end{array}$ & $\begin{array}{l}\text { 1535, oficio } 6 \text {, } \\
\text { fo } 891 \mathrm{rv} \text {. }\end{array}$ \\
\hline institución & San Mateo & El Salvador & Hospital Sangre & \\
\hline número & 2 & 1 & 3 & \\
\hline $\begin{array}{l}\text { reseña } \\
\text { documental }\end{array}$ & $\begin{array}{l}\text { 1537, oficio 6, } \\
\text { fo } 884 \text { rv.; } 1546 \text {, } \\
\text { oficio 8, fo } 292 \text { rv. }\end{array}$ & $\begin{array}{l}\text { 1542, oficio 5, } \\
\text { fo } 1031 \mathrm{v} \text {. }\end{array}$ & $\begin{array}{l}\text { 1537, oficio3, } \\
\text { fo 416v.; 1543, } \\
\text { oficio 8, fo } \\
\text { 519v.; } \\
\text { 1548, oficio 8, } \\
\text { fo } 750 \mathrm{v} \text {. }\end{array}$ & \\
\hline \multicolumn{4}{|c|}{ total } & 13 \\
\hline
\end{tabular}

Como vemos, el monasterio de San Francisco y el Hospital de la Sangre se llevan la mayoría de los casos de celebración del cabo de los nueve días, en la misma línea que ocurre con los novenarios (excepto la Colegial de El Salvador, donde sólo se manda celebrar un cabo de nueve días), cosa lógica pues el cabo se intentaría realizar en el mismo lugar que el novenario.

Misas de año. En cuanto a misas por año y cabo de año, se trataba en el primer caso de ofrecer una misa cada semana, por tanto 52 en el año, más otra (que podía ser más solemne) al finalizar dicho primer año tras el óbito del testador. Las que hemos documentado figuran distribuidas entre las siguientes iglesias.

TABLA ESTADÍSTICA № 10

Lugar de celebración de las misas de año y cabo de año

\begin{tabular}{|c|c|c|c|c|}
\hline $\begin{array}{l}\text { Iglesia/ } \\
\text { Hospital }\end{array}$ & San Francisco & San Lucas & San Marcos & Hospital Sangre \\
\hline número & 1 & 3 & 2 & 1 \\
\hline $\begin{array}{l}\text { reseña } \\
\text { documental }\end{array}$ & $\begin{array}{l}\text { 1541, oficio 3, } \\
\text { fo } 847 \text { rv. }\end{array}$ & $\begin{array}{l}\text { 1545, oficio 8, } \\
\text { fo 682rv.; 1541, } \\
\text { oficio 3, fo } \\
\text { 847rv.; } \\
\text { 1537, oficio 2, } \\
\text { fo 728rv. }\end{array}$ & $\begin{array}{l}\text { 1490, } \\
\text { Bartolomé } \\
\text { de Maya, fo } \\
\text { 63rv.; } \\
\text { 1535, oficio 6, } \\
\text { fo 891rv. }\end{array}$ & $\begin{array}{l}\text { 1537, oficio 3, } \\
\text { fo 416v. }\end{array}$ \\
\hline \multicolumn{4}{|l|}{ total } & 7 \\
\hline
\end{tabular}

Observamos que son pocos quienes instituyen tal misa por año y cabo de año, teniendo la mayor frecuencia la iglesia de San Lucas y cantidades menores San Marcos, San Francisco y Santiago. En todo caso, parece claro que no era muy usual mandar tal celebración por la memoria del difunto.

Otras misas. Referido a otras misas dispuestas por los testadores que se han de celebrar al objeto de facilitar su tránsito al paraíso, exceptuando treintanarios y remembranzas que tratamos aparte, hemos hallado quince casos en que no se especifica tal extremo; nueve a elección de los albaceas; cinco a criterio de los hermanos mayores del Hospital de la Misericordia, y uno (el novicio franciscano Benito Restrojo sólo señala "... e me digan las obsequias que se acostunbran haser a los otros frayles de la dicha horden"). ${ }^{103}$

Comencemos por las trece misas de la luz ("se llaman así en razón del número de velas o de luces que durante ellas ardían"), ${ }^{104}$ cuyos ordenantes recogemos en la tabla siguiente, de acuerdo con el lugar donde prefieren que se digan por su intención.

TABLA ESTADÍSTICA № 11

Lugar de celebración de las trece misas de la luz

\begin{tabular}{|c|c|c|}
\hline institución & número & reseña documental \\
\hline Madre de Dios & 1 & 1544, oficio 5, fo 778 rv. \\
\hline Merced & 1 & 1542, oficio 3 , fo $624 r v$. \\
\hline Misericordia & 1 & 1540, oficio 5 , fo $405 \mathrm{v}$. \\
\hline San Dionisio & 2 & 1537, oficio 6, fo 271v.; 1544 , oficio 2, fo 591rv. \\
\hline San Juan de Letrán & 4 & $\begin{array}{l}\text { 1528, oficio 7, fo 60v.; } 1540 \text {, oficio 2, fo } 492 \mathrm{v} \text {; } \\
\text { 1540, oficio 5, fo } 290 \mathrm{v} \text {.; } 1546 \text {, oficio 2, fo } 357 \mathrm{v} \text {. }\end{array}$ \\
\hline San Lucas & 1 & 1545, oficio 8 , fo 682 rv. \\
\hline San Marcos & 2 & 1536, oficio 7, fo 359v.; 1543 , oficio 7, fo $477 \mathrm{rv}$. \\
\hline San Francisco & 9 & $\begin{array}{l}\text { 1511, oficio 2, fo 567v. (dos mandas); 1528, } \\
\text { oficio 8, fo 485rvv; 1534, oficio 6, fo 419r.; 1538, } \\
\text { oficio 2, fo 529rv.; 1538, oficio 7, fo 848rv.; 1539, } \\
\text { oficio 5, fo 461rv.; 1542, oficio 5, fo 1031rv.; 1543, } \\
\text { oficio 8, fo 890rv. }\end{array}$ \\
\hline San Mateo & 2 & 1537, oficio 6, fo 884rv.; 1546 , oficio 8, fo 292rv. \\
\hline San Miguel & 3 & $\begin{array}{l}\text { 1530, oficio 8, fo } 710 \text { rv.; } 1535 \text {, oficio } 5 \text {, fo roto rv.; } \\
1549 \text {, oficio } 18 \text {, fo } 166 \mathrm{v} \text {. }\end{array}$ \\
\hline El Salvador & 2 & 1527, oficio 8, fo 565rv.; 1547, oficio 5, fo 290rv. \\
\hline Hospital Sangre & 3 & $\begin{array}{l}\text { 1533, oficio } 3 \text {, fo roto rv.; } 1543 \text {, oficio 8, fo 519v.; } \\
\text { 1548, oficio 8, fo } 750 \mathrm{v} \text {. }\end{array}$ \\
\hline Santiago & 2 & 1531, oficio 7, fo 286v.; 1550 , oficio 11 , fo 1307 rv. \\
\hline Sto Domingo & 1 & 1523, oficio 1, fo $32 v$. \\
\hline Nra Sra de Guía & 1 & 1544, oficio 8 , fo 592 rv. \\
\hline Donde digan albaceas & 1 & 1537, oficio 2, fo 728 rv. \\
\hline total & 36 & \\
\hline
\end{tabular}

La diferencia entre quienes desean tal celebración en el Convento de los franciscanos y el resto es más que apreciable: un cuarto del total prefieren dichas misas en el Convento de San Francisco (volveríamos a hacer referencia al predicamento del santo de Asís). El resto aparece muy disperso por las diferentes iglesias, monasterios y hospitales de la ciudad.

Continuaremos por las misas que se ordenan decir por el eterno descanso de las almas de los familiares difuntos y que recogemos en una nueva tabla.

103 AHMJF, APN, oficio 5, Rodrigo de Rus, fo 1073rv., 17 de agosto de 1539.

104 Pérez González, S. Mạ. 2005: 66. 
TABLA ESTADÍSTICA № 12

Misas por familiares difuntos ${ }^{105}$

\begin{tabular}{|c|c|c|c|c|c|c|c|c|c|c|c|}
\hline institución & padre & madre & padres & abuelos & hermanos & marido & mujer & hijos & suegros & suegro y tío & total \\
\hline Cartuja & & 10 & & & & & & & & & 10 \\
\hline Guía & & & & & & & & & & 6 & 6 \\
\hline Madre de Dios & & & 30 & & & & & & & & 30 \\
\hline Merced & & & 10 & & & & & & & & 10 \\
\hline Misericordia & & & 10 & & & & & & & & 10 \\
\hline San Francisco & 15 & & 62 & & & & & & & & 77 \\
\hline San Juan & & & & & & & 1 & & & & 1 \\
\hline San Juan de Letrán & & 5 & 14 & & 3 & & & & & & 22 \\
\hline San Marcos & & & 40 & & 10 & 10 & & & & & 60 \\
\hline San Mateo & & & 4 & & & & & & & & 4 \\
\hline San Miguel & 4 & & 19 & 2 & & 2 & & & 2 & & 29 \\
\hline Hospital Sangre & & & 30 & & & & & & & & 30 \\
\hline Santiago & & & 16 & & & & 6 & & & & 22 \\
\hline $\mathrm{St}^{0}$ Domingo & 8 & 1 & 42 & & & 10 & & 10 & & & 71 \\
\hline Victoria & & & 2 & & & & & & & & 2 \\
\hline Tarifa & & & 2 & & & & & & & & 2 \\
\hline total & 27 & 16 & 281 & 2 & 13 & 22 & 7 & 10 & 2 & 6 & 386 \\
\hline
\end{tabular}

Está clara la devoción por los padres, o sea, la aplicación del cuarto mandamiento, pues si a los 281 casos que registramos de ambos progenitores sumamos los 27 por el alma del padre y los 16 por la madre, nos resulta un total de 324 misas las que se dedican a pedir por las almas de los padres de los testadores, o sea, casi un $85 \%$ de las misas por las almas de familiares están dedicadas a los padres.

A gran distancia se sitúan aquéllas que se mandan por viudas para la salvación del alma de su marido, mientras que a la inversa el número es bastante menor. Por los hermanos, los hijos y los suegros se ordenan pocas misas, siendo anecdóticas las que se ofrendan por los abuelos.

Las que se ordenan por los difuntos y por las almas del Purgatorio las colocamos a continuación en dos nuevos cuadros.

TABLA ESTADÍSTICA № 13

\section{Número de misas ofrecidas por las almas de los} difuntos

\begin{tabular}{|c|c|c|c|c|}
\hline institución & Misericordia & $\begin{array}{c}\text { monasterio sin } \\
\text { especificar }\end{array}$ & San Dionisio & San Francisco \\
\hline número & 10 & 100 & $\begin{array}{c}\text { número sin } \\
\text { determinar }\end{array}$ & $\begin{array}{c}20 \text { más número } \\
\text { sin determinar }\end{array}$ \\
\hline institución & San Lucas & San Marcos & El Salvador & Santiago \\
\hline número & 8 & 10 & 11 & 11 \\
\hline
\end{tabular}

105 En el monasterio de San Francisco, además de las 62 misas a la memoria de los padres, hay que añadir quince reales en misas por ellos que manda el curtidos genovés estante Bartolomé Mascardo (oficio 1 , Francisco Román de Trujillo, fo 338v., 15 de abril de 1522). Quien ordena se digan en la iglesia de Tarifa dos misas por las almas de sus padres es el portugués Françisco Vaes, vecino de Cubillana y estante en Jerez (oficio 8, Gómez Patiño, fo 984v., 17 de octubre de 1546).
Observamos nuevamente que la mayoría se pretende oficiar en el Convento de San Francisco (si obviamos las cien que se mandan en cenobio no especificado), y cantidades similares (en torno a diez misas) en las iglesias de Santiago, El Salvador, San Marcos y San Lucas (San Dionisio aparece sin conocerse el número exacto de misas) y el Hospital de la Misericordia.

TABLA ESTADÍSTICA № 14

Número de misas ofrecidas por las almas del Purgatorio

\begin{tabular}{|c|c|c|c|c|}
\hline institución & Cartuja & Madre de Dios & Merced & Misericordia \\
\hline número & 5 & 30 & 4 & 6 \\
\hline institución & $\begin{array}{c}\text { monasterio sin } \\
\text { especificar }\end{array}$ & San Dionisio & San Francisco & $\begin{array}{c}\text { San Juan de } \\
\text { Letrán }\end{array}$ \\
\hline número & 100 & $\begin{array}{c}\text { número sin } \\
\text { determinar }\end{array}$ & 74 & 12 \\
\hline institución & San Lucas & San Marcos & San Mateo & San Miguel \\
\hline número & 5 & 15 & 14 & 1 \\
\hline institución & El Salvador & Hospital Sangre & Sto Domingo & Victoria \\
\hline número & 74 & 1000 & 2 & 12 \\
\hline
\end{tabular}

Sobresale, con diferencia, el número de misas que por las almas del Purgatorio se mandan ofrecer en el Hospital de la Sangre. Tras él, con cantidades similares aparecen El Salvador y San Francisco, y cantidades mucho más modestas el resto.

Terminaremos con el lugar de celebración de misas que se encargan por las ánimas de personas de las que se tiene "encargo". 
TABLA ESTADÍSTICA № 15

Número de misas encargadas por las almas de determinadas personas

\begin{tabular}{|l|c|c|c|c|c|c|}
\hline institución & $\begin{array}{c}\text { Madre de } \\
\text { Dios }\end{array}$ & Merced & Misericordia & $\begin{array}{c}\text { San } \\
\text { Francisco }\end{array}$ & $\begin{array}{c}\text { San Juan } \\
\text { de Letrán }\end{array}$ & $\begin{array}{c}\text { San } \\
\text { Marcos }\end{array}$ \\
\hline número & 10 & 5 & 6 & 26 & 12 & 10 \\
\hline institución & El Salvador & Sangre & Santiago & Victoria & $\begin{array}{c}\text { sin } \\
\text { especificar }\end{array}$ & \\
\hline número & 25 & 7 & 5 & 12 & 5 & 123 \\
\hline total
\end{tabular}

Nuevamente hallamos que San Francisco y El Salvador constituyen los lugares predilectos para ofrecer misas por las almas de personas de quien se tiene cargo, apareciendo con frecuencias bastante menores el resto.

Las misas de san Amador (se dice que eran 33) deben su nombre al citado santo, el cual parece que "La popularidad de las misas de san Amador debió ceñirse, pues, al siglo xV y primera mitad del XVI... San Amador había recibido la gracia de conocer en vida el estado en que se hallaban las almas de sus padres. Después las había sacado del purgatorio dedicándole las misas requeridas". ${ }^{106}$

Nosotros solamente hemos localizado una manda de este tipo, la que realiza la portuguesa Catalina Mendes, vecina en San Miguel, quien en 1548 testa y dice que quiere ser sepultada en el Monasterio de San Francisco y con el hábito de dicha Orden y además manda que en dicho monasterio le digan otra misa y vigilia de réquiem cantada de cuerpo presente y cinco misas rezadas "en honor y reverençia de las çinco llagas e por las ánymas del Purgatorio e por my intención e otras çinco misas reçadas del santo Amador e otras diez misas por my ányma" y den la costumbre. ${ }^{107}$

Parecida significación tienen las llamadas misas del Conde (también 33), de la que sólo hemos hallado una manda, la que corresponde al testamento del genovés Juan Peres Peçano, vecino en San Juan, quien "manda que se digan por su ánima las treynta e tres misas del conde e que se digan en la dicha yglesia de San Marcos", donde desea ser sepultado "dentro en la yglesia de San Marcos desta çibdad en el sepultura que ay está de su abuelo". ${ }^{108}$

En todo caso, el Concilio de Trento condenará tanto unas como otras (santo Amador, Conde y otras de san Vicente). ${ }^{109}$

Votos. Las noticias que sobre votos hemos recogido se refieren al incumplimiento de determinadas obligaciones que correspondían a los testadores como hijos de personas que habían instituido capellanías o mandado que les hicieran determinadas fiestas o remembranzas y los hijos no las habían cumplido. Por ello mandan a su vez a sus herederos y albaceas que sean ellos los que de manera definitiva hagan realidad los deseos de dicho antepasado.

106 Martínez Gil, F. 2000. Muerte y sociedad en la España de los Austrias: 233, Universidad de Castilla La Mancha.

107 AHMJF, APN, oficio 5, Rodrigo de Rus, fo roto v., 12 de septiembre de 1548.

108 AHMJF, APN, Bartolomé de Maya, fo 63rv., domingo 28 de marzo de 1490 .

109 García Pedraza, A. 2002. Actitudes ante la muerte en la Granada del siglo XVI: 713, Universidad de Granada.
El primer caso que hallamos corresponde al veinticuatro Françisco Adorno: en su testamento de 1538 (hizo otro en 1545$)^{110}$ y el segundo ejemplo está representado por la genovesa Catalina Peçano, vecina en El Salvador, quien declara que su madre -Ynés Nuñes- dejó 200 maravedís de tributo sobre unas casas en la collación de San Mateo, para el pago de cuatro remembranzas en el Monasterio del Espíritu Santo. Como ella los vendió redimiendo el censo, manda que se compren otros 200 maravedís de tributo para que se den al dicho monasterio y se digan las cuatro remembranzas por su madre. ${ }^{111}$

\section{Mandas testamentarias}

\section{Mandas artísticas}

Con la denominación de mandas artísticas nos referimos a aquellas mandas testamentarias en que los intitulantes de los testamentos ordenan la entrega de determinadas cantidades de dinero a iglesias y monasterios con destino a la realización de capillas, obras de reparación de la fábrica del edificio o del altar del mismo, o ropa con destino a su uso litúrgico o para colocar a las imágenes, etc. La relación completa de las mandas artísticas que hemos hallado figura en la siguiente tabla.

TABLA ESTADÍSTICA № 16

Mandas artísticas de los testadores extranjeros en Jerez

\begin{tabular}{|l|l|l|l|}
\hline reseña & \multicolumn{1}{|c|}{ testador } & \multicolumn{1}{|c|}{ beneficiario } & \multicolumn{1}{c|}{ manda } \\
\hline $\begin{array}{l}\text { 1511, oficio 2, } \\
\text { fo 567v. }\end{array}$ & Juan Rodrigues & San Francisco & $\begin{array}{l}\text { 4.000 maravedís para } \\
\text { obras y reparos. }\end{array}$ \\
\hline $\begin{array}{l}\text { 1513, oficio 7, } \\
\text { fo 819rv. }\end{array}$ & $\begin{array}{l}\text { Juan Martines de } \\
\text { los Castelaos }\end{array}$ & $\begin{array}{l}\text { Iglesia de } \\
\text { Sedesylves }\end{array}$ & $\begin{array}{l}\text { 600 maravedís para la } \\
\text { obra de la iglesia. }\end{array}$ \\
\hline $\begin{array}{l}\text { 1528, oficio 4, } \\
\text { fo 743rv. }\end{array}$ & Juan Terrin & Nra Sra de Guía & Un ducado para la obra. \\
\hline $\begin{array}{l}\text { 1533, oficio 3, } \\
\text { fo roto rv. }\end{array}$ & Domingo Hernandes & Nra Sra de Guía & Un ducado para la obra \\
\hline $\begin{array}{l}\text { 1535, oficio 2, } \\
\text { fo 451v. }\end{array}$ & Da María Adorno & Nra Sra de Guía & Casulla de damasco \\
\hline $\begin{array}{l}\text { 1542, oficio 3, } \\
\text { fo 624rv. }\end{array}$ & Da Clara Marrufo & $\begin{array}{l}\text { Monasterio } \\
\text { Merced }\end{array}$ & $\begin{array}{l}\text { Tres albas y una saya y } \\
\text { un manto para la Virgen }\end{array}$ \\
\hline $\begin{array}{l}\text { 1542, oficio 3, } \\
\text { fo 624rv. }\end{array}$ & Da Clara Marrufo & $\begin{array}{l}\text { Iglesia San } \\
\text { Alifonso }\end{array}$ & $\begin{array}{l}\text { Una casulla, un alba y } \\
\text { un ornamento }\end{array}$ \\
\hline $\begin{array}{l}\text { 1548, oficio 7, } \\
\text { fo 237v. }\end{array}$ & Juan Martín & Iglesia Santiago & 375 maravedís para retablo \\
\hline $\begin{array}{l}\text { 1548, oficio 11, } \\
\text { fo 554v. }\end{array}$ & Ginebra Luys & Iglesia Santiago & $\begin{array}{l}\text { Un paño de rostro labrado } \\
\text { para imagen de la Virgen }\end{array}$ \\
\hline
\end{tabular}

110 AHMJF, APN, oficio 7, Luis de Llanos, fo 163rv., 22 de febrero de 1538: declara que "el jurado Françisco Adorno, mi abuelo, en su testamento e postrimera voluntad que hizo e otorgó so el qual murió, dexó e mandó que en la yglesia de San Marcos desta çibdad se hiziese vna capilla, y Leonís Adorno, su hijo, mi padre, me dexó çierta mejoría de bienes para que la dicha capilla se hiziese, e no se a hecho. Mando... que dende el día que de mí acaeçiere finamiento en adelante la dicha capilla se haga e labre llanamente en la dicha yglezia de San Marcos, e no se alçe mano della hasta se acabar de labrar y todo lo que en ello se gastare que se cunplan e paguen de mis bienes...".

111 AHMJF, APN, oficio 8, Francisco del Mercado, fo 565rv., 21 de octubre de 1527. 
Observamos en la tabla que la mayoría se dedican a la ermita de Nuestra Señora de Guía, por parte de genoveses y portugueses. Consisten en general en donativos para facilitar la obra de la fábrica, así como para reparaciones.

El caso más destacado es sin duda el de la genovesa Clara Marrufo. ${ }^{112}$ Otro de los ordenantes es el genovés Juan Terrin "natural de la villa de Laprya que es tierra de la çibdad de Génova", el cual quiere ser enterrado en San Juan de Letrán y entre sus mandas hallamos un ducado a Nuestra Señora de Guía "para la obra". Pero es que además ordena otros legados a iglesias de su tierra, como recoge la siguiente manda: "que den de mis bienes para la obra de la capilla de San Sevastián que está dentro en la yglesia de San Niculoso del dicho lugar de Lapria" un ducado; para la obra de la iglesia de Nuestra Señora de Para "que es en el lugar que se dize Aloa" un ducado; otro ducado a la obra del señor Santiago de la iglesia de Tove que es en tierra de Serfinal y otro ducado para la obra de la iglesia de San Roque en Lapria. ${ }^{113}$
También registramos dos donantes para la iglesia de Santiago: la portuguesa Ginebra Luys ${ }^{114}$ y su paisano Juan Martín, vecino de la misma collación, en la calle Pozo del Olivar. ${ }^{115}$

La cantidad mayor que hemos registrado es la que manda el portugués Juan Rodrigues, vecino en Santiago, en 1511 y que se eleva a 4.000 maravedís para la obra y reparaciones del Monasterio de San Francisco (lugar donde quiere ser enterrado y amortajado con el hábito de la Orden). ${ }^{116}$

\section{Misas especiales}

Como misas especiales agrupamos todas aquellas mandas de misas que no se configuran en los apartados que hemos recogido hasta aquí y que se dedican a especiales advocaciones: a las Cinco Llagas de Jesucristo, a la Pasión, a Santo Amador, etc. Las reflejamos en el cuadro que sigue.

TABLA ESTADÍSTICA № 17

Número de misas especiales, lugar de celebración y ordenantes de las mismas

\begin{tabular}{|c|c|c|c|c|c|c|c|}
\hline tipo & Cinco Llagas & Doce apóstoles & Magdalena & Once mil vírgenes & Pasión & San Gregorio & Santo Amador \\
\hline $\mathrm{n} \cong$ misas & 25 & 12 & 5 & 11 & 55 & 5 & 5 \\
\hline lugar & $\begin{array}{l}10 \text { en San Francisco; } 5 \text { en } \\
\text { San Juan de Letrán; } 5 \text { en la } \\
\text { Merced y } 5 \text { en San Lucas. }\end{array}$ & San Marcos & San Marcos & Sto Domingo & $\begin{array}{l}5 \text { en Sto Domingo } \\
\text { y } 50 \text { en San } \\
\text { Marcos. }\end{array}$ & $\begin{array}{l}\text { Ntra Sra de la } \\
\text { Victoria }\end{array}$ & San Francisco \\
\hline intitulantes & $\begin{array}{l}\text { Juan Fernandes, portugués, } \\
\text { en 1528, oficio 8, fo } \\
\text { 485rv.; Marcos Gonçales, } \\
\text { portugués, en 1532, } \\
\text { oficio 10, fo 910v.; Antono } \\
\text { Marques, genovés, en } \\
\text { 1543, oficio 7, fo 477rv.; } \\
\text { doña Lequina Despíndola, } \\
\text { genovesa, en 1545, oficio 8, } \\
\text { fo 682rv.; Catalina Mendes, } \\
\text { portuguesa, en 1548, oficio } \\
\text { 5, fo roto v. }\end{array}$ & $\begin{array}{l}\text { Françisco Adornio, } \\
\text { genovés, en 1545, } \\
\text { oficio } 1, \text { fo } 307 v \text {. }\end{array}$ & $\begin{array}{l}\text { Françisco Adornio, } \\
\text { genovés, en 1545, } \\
\text { oficio } 1, \text { fo } 307 v \text {. }\end{array}$ & $\begin{array}{l}\text { Juan Álvares, } \\
\text { portugués, en } \\
1535 \text {, oficio 5, fo } \\
\text { 560v. }\end{array}$ & $\begin{array}{l}\text { Antono Marques, } \\
\text { genovés, en } 1543 \\
\text { oficio } 7 \text {, fo } 477 \mathrm{rv} . ; \\
\text { Françisco Adornio, } \\
\text { genovés, en } 1545 \text {, } \\
\text { oficio } 1 \text {, fo } 307 \mathrm{v} \text {. }\end{array}$ & $\begin{array}{l}\text { Antono Marques, } \\
\text { genovés, en 1543, } \\
\text { oficio 7, fo 477rv. }\end{array}$ & $\begin{array}{l}\text { Catalina Mendes, } \\
\text { portuguesa, en } \\
1548 \text {, oficio 5, fo } \\
\text { roto v. }\end{array}$ \\
\hline \multicolumn{7}{|l|}{ total } & 118 \\
\hline
\end{tabular}

112 AHMJF, APN, oficio 3, Rodrigo de Cuenca, fo 624rv., 29 de agosto de 1542: manda para la iglesia de San Ildefonso que "de vna saya de alty y baxo carmezí mía se faga vn hornamento para la dicha yglezia del señor Sant Alifonso, con el qual se diga misa en la dicha yglezia en la capilla della donde yo y el dicho Martín Dávila, mi marido, estuviéremos enterrados; y así mismo mando para el serviçio de la dicha capilla vna cazulla de razo naranjado e vna alva que yo tengo enpeçada, la qual se acabe con todo su recabdo, para que con ello ordinariamente se sirva la dicha capellanía". Al monasterio de la Merced le regala "vna saya de terçiopelo negro mía como yo la para que della se haga para Nuestra Señora vna saya e vn manto y no para otro efeto", y además pide "por merçed y encargo el dicho Martín Dávila... que vn terno de brocado que tiene cortado y enpeçado a faser para el monasterio de Nuestra Señora de la Merçed desta çibdad lo mande acabar de faser, con tres alvas y todo recabdo y cordones que para ello fueren menester con toda brebedad y sobre el dicho brocado... se gaste de mis bienes la mitad de todo lo que costare..."

113 AHMJF, APN, oficio 4, Juan Rodríguez, fo 743rv., 16 de septiembre de 1528.
Destacan sobremanera las misas de la Pasión (con 55 mandas), siguiendo a continuación las que se ofrecen a las Cinco Llagas (o Plagas) de Cristo. ${ }^{117}$

114 AHMJF, APN, oficio 18, Simón García Copín, fo 554 v., 16 de abril de 1548: vecina en la calle Lealas de la collación de Santiago, quien ordena su entierro en el Hospital de la Sangre (de dicha collación) y manda unos manteles para el altar del Hospital " $y$ vn paño de rostro labrado que tengo a Nuestra Señora, que está en la yglesia del señor Santiago".

115 AHMJF, APN, oficio 7, Luis de Llanos, fo 237v., 26 de julio de 1548: también desea ser sepultado en dicho Hospital y manda 375 maravedís "para las obras del retablo de la dicha yglesia de Santiago para dorar el dicho retablo...".

116 AHMJF, APN, oficio 2, Sebastián Gaitán, fo 567v., 9 de septiembre de 1511.

117 Baldó Alcoz, J. 2006. "Las misas post mortem: simbolismos y devociones en torno a la muerte y el más allá en la Navarra bajomedieval”, Zainak 28: 353-374: “... las cinco misas en recuerdo de las cinco llagas que se habían practicado a Cristo suponen una valoración del 5 como símbolo del hombre, de la salud y del amor, de los cinco sentidos y, por extensión, de la materia" (p. 367). 
Resulta significativamente mucho menor las que se dicen por otras devociones. Alguna de ellas las ordenan genoveses exclusivamente (caso de las de san Gregorio y que parecen ser una modalidad de treintanario) $)^{118}$ y las dedicadas a los Doce Apóstoles ("El doce es un número con un simbolismo excepcional dentro del panorama medieval y del mundo cristiano, debido a que es el resultado del producto del tres y el cuatro, y tendría un matiz tan destacado como el siete").

Treintanarios. Se conocían con el nombre de treintanarios las misas que se decían por la intención del ánima del difunto y de los que él pidiera y que se celebraban a lo largo de un mes (treinta misas seguidas). Recogemos en la tabla siguiente el carácter abierto o cerrado (los clérigos se encerraban en la iglesia o monasterio correspondiente sin tener comunicación con el exterior durante dicho plazo) de dichas celebraciones litúrgicas, así como el lugar de realización de las mismas y la nacionalidad de los ordenantes.
Observamos que son los genoveses los más dados a ordenar la celebración de tales exequias, en número bastante mayor que los portugueses, siendo muy pocos los franceses que los ordenan.

En cuanto a los lugares de celebración de los mismos vuelve a destacar el Convento de San Francisco, seguido por la iglesia de El Salvador y, desde luego, predominan los treintanarios abiertos (veintiséis, es decir, más del 85 por ciento) sobre los cerrados (sólo cuatro de treinta).

Remembranzas. Las remembranzas eran unos oficios especiales que el testador mandaba decir en determinado día de fiesta a lo largo de un período determinado de tiempo (a veces, con carácter perpetuo), y en dicha manda especificaba en qué había de consistir, así como el dinero que instituía para el pago a la correspondiente iglesia o monasterio por tal celebración.

TABLA ESTADÍSTICA № 18 Treintanarios encargados en los testamentos ${ }^{120}$

\begin{tabular}{|c|c|c|c|c|c|}
\hline institución & iglesia de Albufera & Merced & Misericordia & San Dionisio & San Francisco \\
\hline abierto & 1 & & 1 & 3 & $4+3$ \\
\hline cerrado & & 1 & & & 2 \\
\hline reseña documental & 1513, oficio 7, fo 819rv. & 1542, oficio 3 , fo $624 r v$. & 1536, oficio 6, fo 708v. & $\begin{array}{l}\text { 1537, oficio } 6 \text {, fo } 271 v \text {. } \\
\text { (tres). }\end{array}$ & $\begin{array}{l}\text { 1511, oficio 2, fo 567v.; 1539, oficio 5, } \\
\text { fo 461rv.; 1543, oficio 5, fo 1256rv.; 1543, } \\
\text { oficio 7, fo 477rv.; } 1547 \text {, oficio 5, fo 241rv.; } \\
\text { 1539, oficio 5, fo 1073rv. (cuatro). }\end{array}$ \\
\hline institución & San Juan de Letrán & San Lucas & San Marcos & San Mateo & San Miguel \\
\hline abierto & 1 & 1 & 2 & 2 & 1 \\
\hline \multicolumn{6}{|l|}{ cerrado } \\
\hline reseña documental & 1528, oficio 4, fo 743rv. & 1545 , oficio 8 , fo 682 rv. & $\begin{array}{l}\text { 1521, oficio 3, fo } 175 \mathrm{v} \text {.; } \\
1537 \text {, oficio 2, fo } 728 \mathrm{rv} \text {. }\end{array}$ & $\begin{array}{l}\text { 1546, oficio 8, fo } 292 \mathrm{rv} \\
\text { (dos) }\end{array}$ & 1535, oficio 5 , fo roto rv. \\
\hline institución & El Salvador & Sangre & Santiago & donde diga su hermano & \\
\hline abierto & 5 & 1 & & 1 & \\
\hline cerrado & & & 1 & & \\
\hline reseña documental & $\begin{array}{l}\text { 1527, oficio 8, fo 565rv.; } \\
\text { 1542, oficio 5, fo 1031v } \\
\text { (dos); 1548, oficio 12, } \\
\text { fo } 1330 v \text { v; } 1550 \text {, oficio 5, } \\
\text { fo ileg. v. }\end{array}$ & 1543, oficio 8, fo $519 v$. & 1536, oficio 7, fo 359v. & 1540, oficio 7, fo 682rv. & \\
\hline \multicolumn{5}{|c|}{ total treintanarios abiertos } & 26 \\
\hline \multicolumn{5}{|c|}{ total treintanarios cerrados } & 4 \\
\hline nación & Francia & Génova & Portugal & & total \\
\hline ordenantes & 2 & 17 & 5 & & 24 \\
\hline
\end{tabular}

118 Pérez González, S. Mạ. 2005: 55, la fiesta de "san Gregorio Magno (590-604), papa y doctor de la Iglesia, que se celebra el 12 de marzo... primer monje elevado a la silla pontificia, en el año 590. Su labor fue extensa: se esforzó en la cristianización de los pueblos germanos, reformó la liturgia y el latín eclesiástico". Sobre las misas de San Gregorio, Baldó Alcoz, J. 2006: 361: “caben destacarse, en primer lugar, las treintenas de misas de Réquiem, o misas de San Gregorio, consistentes en oficios de treinta misas oficiadas durante un período limitado de un mes".

119 Baldó Alcoz, J. 2006: 370.

120 En el monasterio de San Francisco aparecen 4+3 significando cuatro a decir en dicho monasterio de Jerez y tres en el homónimo de Olivencia. Evidentemente no tienen por qué coincidir el número de treintanarios con el de personas que ordenan tal celebración en su testamento, ya que hay quien encarga dos y hasta tres treintanarios: además de por su alma, por la de algún familiar suyo (padres, hijos, etc.). 
TABLA ESTADÍSTICA № 19

Remembranzas ordenadas en los testamentos

\begin{tabular}{|c|c|c|c|c|c|}
\hline lugar & Concepción & Espíritu Santo & Madre de Dios & Merced & San Juan de Letrán \\
\hline número & 2 & 5 & 1 & 1 & 1 \\
\hline día & Encarnación 1; Concepción 1. & $\begin{array}{l}\text { Asunción 1; Sta María de agosto 1; } \\
\text { Concepción 1; Nra Sra de la } 0 \text { 1, y Nra Sra } \\
\text { de setiembre } 1 .\end{array}$ & Encarnación & Encarnación & Nra Sra del Rosario \\
\hline ordenante & $\begin{array}{l}\text { Doña María Adornio, 1522, } \\
\text { oficio } 7 \text {, fo 526rv. }\end{array}$ & $\begin{array}{l}\text { Catalina Peçano, 1527, oficio 8, fo 565rv., y } \\
\text { 1549, oficio 2, fo } 911 \mathrm{v} \text {. }\end{array}$ & $\begin{array}{l}\text { Juan Alonso, } 1544 \text {, } \\
\text { oficio } 10 \text {, fo } 663 \mathrm{v} \text {. }\end{array}$ & $\begin{array}{l}\text { Doménigo de Mafe, 1531, } \\
\text { oficio } 2 \text {, fo } 459 \mathrm{v} .\end{array}$ & $\begin{array}{l}\text { Juan Batista Carlava, } \\
\text { 1540, oficio 2, fo } 492 \mathrm{v} \text {. }\end{array}$ \\
\hline lugar & San Marcos & El Salvador & Sangre & Sto Domingo & \\
\hline número & 4 & 6 & 1 & 2 & \\
\hline día & $\begin{array}{l}\text { Inicio mes } 1 \text {; mediado mes } 1 \text {; } \\
\text { fin mes } 1 \text {, y sin indicar } 1 .\end{array}$ & $\begin{array}{l}\text { Asunción 2; Encarnación 1; Visitación 1; } \\
\text { Veracruz 1, y ante imagen Nra Sra Antigua } \\
1 .\end{array}$ & Candelaria & $\begin{array}{l}\text { Candelaria } 1 \text {; día que digan } \\
\text { sus albaceas } 1 .\end{array}$ & \\
\hline ordenante & $\begin{array}{l}\text { Françisco Adorno, 1538, oficio } \\
\text { 7, fo 163rv.; Hernando Tirado } \\
\text { 1537, oficio 3, fo } 461 \mathrm{v} \text {. }\end{array}$ & $\begin{array}{l}\text { Catalina Peçano, 1549, oficio 2, fo 911v.; } \\
\text { Catalina la griega, 1542, oficio 5, fo } \\
\text { 1031rv., y 1550, oficio 5, fo ileg. v.; Luys de } \\
\text { Espíndola, 1539, oficio 7, fo } 357 \mathrm{v} \text {. }\end{array}$ & $\begin{array}{l}\text { Hernando Tirado, } \\
\text { 1537, oficio } 3, \text { fo } \\
461 v \text {. }\end{array}$ & $\begin{array}{l}\text { Hernando Tirado, 1535, } \\
\text { oficio 6, fo 891rv., y doña } \\
\text { María Adorno, 1535, oficio } \\
\text { 2, fo } 451 v \text {. }\end{array}$ & \\
\hline \multicolumn{5}{|c|}{ total número remembranzas } & 23 \\
\hline \multicolumn{5}{|c|}{ total ordenantes } & 10 \\
\hline
\end{tabular}

Hemos obtenido un total de veinte y tres remembranzas que se han de celebrar: el día de la Encarnación (cuatro mandas); Asunción (tres); la Concepción y la Candelaria (dos); y una para la Visitación, Santa María de agosto, Santa María de septiembre, Nuestra Señora de la Antigua, Nuestra Señora de la O, Nuestra Señora del Rosario, y la Veracruz, y cinco que no se relacionan de manera directa con ninguna festividad religiosa (a principio, mediado o fin de mes y cuando quieran los albaceas).

La devoción a la Virgen queda más que manifiesta en la preferencia de todos los testadores, pues de las 23 que ordenan, diecisiete corresponden a fiestas marianas, una es cristológica (la Veracruz) y cinco no están explícitas. Alguna presenta el doble aspecto de celebración mariana y cristológica (caso de la Candelaria -presentación de Jesús en el templo-, y la Encarnación).

Capillas. La fundación de una capilla donde ser sepultado, se construya un retablo y se celebren oficios por la memoria del difunto (capellanía) ${ }^{121}$ no es algo que esté al alcance de cualquiera, así que las halladas se relacionan con familias de elevada posición económica, todas ellas genovesas, a excepción de un francés (Juan de Ublete que tenía, al menos, una herencia considerable, pues recibió de sus padres 14.000 ducados y los tiene en guarda Jácome de Lutos, vecino en la collación de Santiago y hermano de su padre). ${ }^{122}$

Los testamentos en que se recogen aparecen reflejados en la tabla 20, en la que registramos año, reseña del documento, testador, lugar donde funda la capilla, así como el

121 Pérez González, S. Mạ. 2005: 96-97, define como: "Se trata de fundaciones creadas con la intención de celebrar anualmente un número determinado de misas, coincidiendo éstas, bien con el aniversario del fundador, o bien con la celebración de una festividad de devoción del difunto. El mantenimiento de estos cultos se sufragaba de dos maneras: se dotaba a la fábrica de la parroquia con determinados bienes para que con sus rentas se pudiese pagar a los clérigos; o se obligaba a los herederos a costear los cultos establecidos en el testamento".

122 AHMJF, APN, oficio 11, Leonís Álvarez, fo 2050v., 4 de diciembre de 1550. patrón o capellán de la misma y la dotación material para su mantenimiento.

En total hemos documentado la erección de seis capillas, siendo el caso más sobresaliente el de los caballeros genoveses Adorno. Su capilla situada en la iglesia de San Marcos (y hoy desaparecida) fue instituida por el patriarca de la familia, el mercader, cambiador y luego jurado Françisco Adorno, en fecha por determinar en el último cuarto del siglo XV, ya que no hemos registrado su testamento. Sí sabemos la fecha de su muerte (agosto de 1499) a partir del testamento de su hijo Leonís, veinticuatro de Jerez y alcaide y corregidor de Arcos de la Frontera. ${ }^{123}$

No parece que dicha capilla estuviera especialmente bien servida, ya que tanto el hijo (Leonís), como el nieto (Françisco, veinticuatro asimismo), reconocen en sus testamentos la dejadez de que han hecho gala a la hora de cumplir la voluntad de su antecesor. Así Leonís declara que heredó de su padre Françisco Adornio el tercio y quinto de sus bienes de mejoría, con cargo de que hiciese servir la capellanía que instituyó en San Marcos, mandando que su hijo Françisco Adornio, veinticuatro, repare dicha falta. ${ }^{124} \mathrm{EI}$

123 AHMJF, APN, oficio 3, Rodrigo de Cuenca, fo 175v., 22 de abril de 1521, donde declara que tiene en su poder 25.000 maravedís que dejó por testamento su padre Françisco Adornio para su hijo (y hermano de Leonís) Françisco Adornio; manda que se le paguen y además 2.500 de ganancia cada año; él recibió dicha cantidad en agosto de 1499 "que fue el año (roto) dicho mi señor padre falleçió". Asimismo su viuda, doña Catalina de Figueroa, al testar declara su deseo de ser enterrada con su esposo en San Marcos "en sepultura e capilla que yo tengo donde está enterrado el dicho jurado Françisco Adorno, mi marido", en oficio 2, Sebastián Gaitán, fo 588rv., 3 de agosto de 1506.

124 AHMJF, APN, oficio 3, Rodrigo de Cuenca, fo 175v., 22 de abril de 1521: "aya elleve de mejoría de más de su legytima lo que montare el dicho terçio e quinto de los bienes del dicho Françisco Adornio, mi señor padre, que yo ove y heredé... con tal cargo que el dicho mi hijo, e después dél sus subçesores, sea obligado a haser seruir la dicha capellanía... e a pagar en cada vn año los maravedís o otras cosas que el capellán... oviere de aver... e asy mismo sea obligado el dicho Françisco Adornio, mi hijo, a acabar de haser la dicha capilla que está en la dicha yglesia de San Marcos...". 
TABLA ESTADÍSTICA № 20

Capellanías que aparecen en los testamentos

\begin{tabular}{|c|c|c|c|c|}
\hline reseña & testamentario & lugar & patrón & dotación \\
\hline $\begin{array}{l}\text { 1506, oficio 2, fo } \\
\text { 588rv 3/VIII }\end{array}$ & $\begin{array}{l}\text { Doña Catalina de Figueroa, viuda } \\
\text { del jurado Francisco Adorno. }\end{array}$ & $\begin{array}{l}\text { Iglesia de San Marcos, } \\
\text { capilla del jurado } \\
\text { Francisco Adorno. }\end{array}$ & Su hijo Leonís Adorno. & $\begin{array}{l}\text { De las rentas de sus tierras } 10 \text { cahíces de trigo anuales } \\
\text { para el mantenimiento de su capilla en San Marcos, de } \\
\text { capellán y mayordomo con carácter perpetuo. }\end{array}$ \\
\hline $\begin{array}{l}\text { 1521, oficio } 3, \text { fo } \\
175 v 22 / \text { IV }\end{array}$ & $\begin{array}{l}\text { Leonís Adornio, hijo del jurado } \\
\text { Francisco Adorno. }\end{array}$ & $\begin{array}{l}\text { Iglesia de San Marcos, } \\
\text { capilla del jurado } \\
\text { Francisco Adorno. }\end{array}$ & $\begin{array}{l}\text { Su hijo Francisco Adorno, } \\
\text { veinticuatro. }\end{array}$ & $\begin{array}{l}8.700 \text { maravedís de la renta de la dehesa del Salado; } \\
\text { manda que le sea abonado al clérigo a los plazos de la } \\
\text { obligación que hizo Françisco Adornio. }\end{array}$ \\
\hline $\begin{array}{l}\text { 1538, oficio } 7, \text { fo } \\
163 \text { rv 22/II }\end{array}$ & $\begin{array}{l}\text { Francisco Adorno, veinticuatro } \\
\text { hijo de Leonís Adorno. }\end{array}$ & $\begin{array}{l}\text { Iglesia de San Marcos, } \\
\text { capilla del jurado } \\
\text { Francisco Adorno. }\end{array}$ & Su hijo mayor, Leonís Adorno. & $\begin{array}{l}\text { Censo de } 1.125 \text { maravedís de tributo sobre la mitad de } \\
\text { la venta que tiene camino de El Puerto de Santa María. }\end{array}$ \\
\hline $\begin{array}{l}\text { 1539, oficio } 7, \text { fo } \\
357 v 2 / V\end{array}$ & $\begin{array}{l}\text { Luys de Espíndola, hijo del jurado } \\
\text { Juan Bernal de Gallegos y doña } \\
\text { Luysa de Espíndola. }\end{array}$ & $\begin{array}{l}\text { Iglesia de El Salvador, } \\
\text { capilla de Diego Gonçales } \\
\text { de Gallegos. }\end{array}$ & No indica & 500 maravedís cada año \\
\hline $\begin{array}{l}\text { 1542, oficio 3, fo } \\
\text { 624rv 29/VIII }\end{array}$ & $\begin{array}{l}\text { Doña Clara Marrufo, mujer } \\
\text { del veinticuatro Martín Dávila } \\
\text { Sigüenza. }\end{array}$ & Iglesia de San Ildefonso & Su marido Martín Dávila. & $\begin{array}{l}\text { De sus bienes se compren } 8.000 \text { maravedís de tributo } \\
\text { "los quales quiero... queden perpetuamente por dote } \\
\text { anexos para el serviçio de vna capellanía que yo } \\
\text { ynstituyo e mando que se diga e cante en cada vn año } \\
\text { en la dicha yglezia de Sant Alifonso por mi ánima...". }\end{array}$ \\
\hline $\begin{array}{l}\text { 1545, oficio } 8, \text { fo } \\
\text { 682rv 2/VIII }\end{array}$ & $\begin{array}{l}\text { Doña Lequina de Espíndola, } \\
\text { mujer de Francisco de Morales. }\end{array}$ & $\begin{array}{l}\text { Iglesia de San Lucas "en la } \\
\text { capilla y entierro que alli } \\
\text { tengo". }\end{array}$ & No indica & No indica \\
\hline $\begin{array}{l}\text { 1547, oficio } 2 \text {, fo } \\
857 \mathrm{rv} 3 / \mathrm{XII}\end{array}$ & $\begin{array}{l}\text { Estevanía Peçano, viuda de } \\
\text { Martín de Morón. }\end{array}$ & $\begin{array}{l}\text { Monasterio del Espíritu } \\
\text { Santo }\end{array}$ & Su sobrino Alonso Peçano & $\begin{array}{l}300 \text { maravedís de tributo situados sobre unas casas en } \\
\text { la collación de San Salvador. }\end{array}$ \\
\hline $\begin{array}{l}\text { 1550, oficio } 11 \text {, fo } \\
\text { 2050v } 4 / \text { XII }\end{array}$ & $\begin{array}{l}\text { Juan de Ublete, hijo de Jacobo } \\
\text { Ublete -difunto- y de María } \\
\text { Corteza. }\end{array}$ & $\begin{array}{l}\text { Hospital del Pilar, en } \\
\text { capilla a edificar. }\end{array}$ & $\begin{array}{l}\text { Capellanes: Juan de Herrera, } \\
\text { capellán de dicho hospital, } \\
\text { y Garçía Gutierres, clérigo } \\
\text { presbítero. }\end{array}$ & 30.000 maravedís anuales. \\
\hline
\end{tabular}

nieto, Françisco Adorno, reconoce que "el jurado Françisco Adorno, mi abuelo, en su testamento e postrimera voluntad que hizo e otorgó, so el qual murió, dexó e mandó que en la yglesia de San Marcos desta çibdad se hiziese vna capilla, y Leonís Adorno, su hijo, mi padre, me dexó çierta mejoría de bienes para que la dicha capilla se hiziese, e no se a hecho. Mando... que dende el día que de mí acaeçiere finamiento en adelante la dicha capilla se haga e labre llanamente en la dicha yglezia de San Marcos, e no se alçe mano della hasta se acabar de labrar, y todo lo que en ello se gastare que se cunplan e paguen de mis bienes...". ${ }^{125}$

Sobre la capilla de los Gallegos en la iglesia de El Salvador poco podemos añadir, pues al producirse el colapso del edificio y ser la actual catedral levantada sobre el mismo solar, no queda reliquia alguna de ella.

En el caso de doña Clara Marrufo, ya hemos explicado como los Dávila poseían una capilla dedicada a San Ildefonso en la Colegial de El Salvador, y que como iglesia no llegó a construirse. Suponemos que sería enterrada en El Salvador y allí corrió la misma suerte que la capilla de los Gallegos.

Nada conocemos sobre la capilla instituida por Lequina de Espíndola en la iglesia de San Lucas. No sabemos si sus albaceas y herederos cumplieron la voluntad de la dama o silenciaron dicha obligación (cosa nada infrecuente).

Sobre la capilla instituida por Estevanía Peçano en el Monasterio del Espíritu Santo tampoco hemos podido recabar información, pues la única referencia a una capilla de los

125 AHMJF, APN, oficio 7, Luis de Llanos, fo 163rv., 22 de febrero de 1538 .
Pesaño se sitúa en la iglesia de San Marcos, según la Guía de POMAR y MARISCAL. ${ }^{126}$

Por último, la voluntad del francés Juan de Ublete de que se le hiciese una capilla en el Hospital de Nuestra Señora del Pilar pensamos que cayó en el olvido, ya que la citada institución benéfica también desapareció. ${ }^{127}$

Como hemos apuntado era indispensable dotar económicamente la fundación de tales capellanías ya que, además de proceder en unos casos a su edificación, en todos había que atender su mantenimiento, y ello suponía unos gastos ineludibles en capellán, misas, cera, etc.

Las cantidades que hemos documentado para dicho mantenimiento son variadas. Observamos que van desde cantidades modestas (300 maravedíes anuales hasta los 30.000 que ordenó el francés Juan de Ublete, siendo lo usual algunos miles de maravedíes). Normalmente son

126 Pomar Rodil, P. J. y Mariscal Rodríguez, M. Á. 2004: 54, afirman que "A continuación, y unida a la anterior (capilla de los Grajales) desde el siglo XVIII, se encuentra la capilla de los Pesaño, de la segunda mitad del XV...".

127 Ibídem: 197, señalan que en la parroquia de San Miguel "La capilla del Pilar se encuentra situada... En su interior... destacan... la pequeña escultura de la Virgen del Pilar, acaso obra del siglo XVI, procedente del desaparecido hospital del mismo nombre". Sobre dicho Hospital registramos noticias en las Actas Capitulares, fo 307rv. 29 de agosto de 1530: petición de Martín de Vera, vecino, sobre transformar el hospital del Pilar en monasterio para "... casa y monasterio de monjas donde munchas donçellas pobres y de generaçión se pudiesen reparar y seruir a Dios, y esto consyderado que el dicho Hospital no se advergan otras gentes sino rufianes y personas de mal bivir y que syendo monasterio se repararán munchas donçellas y personas desanparadas...". Se decide que dos veinticuatros y un jurado hagan información del caso. 
cantidades que se obtienen del cobro de censos o tributos sobre diversos bienes (viviendas o fincas rústicas), bien en dinero en metálico, bien en especie (trigo).

\section{Salir sobre la sepultura}

Salir sobre la sepultura era un oficio que consistía básicamente en rezar un responso sobre la sepultura del ordenante que podía celebrar el mismo clérigo que había realizado las demás honras por el finado o bien por otro distinto. Se acompañaba en ocasiones con la cruz y la aspersión de agua bendita sobre el enterramiento. El objetivo no podía ser otro que la oración que facilitase la vía al paraíso del fallecido. (otro), diez días (otro), y trece días (otro); y perpetuamente que, a su vez, se han de celebrar: el día de la Encarnación (dos casos), Todos los Santos (uno), el día de la Candelaria (uno) y coincidiendo con seis misas semanales (otro).

Las que se han de hacer el mismo día del entierro corresponden a once genoveses, ocho portugueses y tres franceses (tabla 21).

Los que ordenan salir sobre su sepultura en días especiales o perpetuamente aparecen en la siguiente tabla: cinco genoveses y dos portugueses son los que prefieren dicha salida en fechas posteriores a su funeral y con ocasión de determinadas fiestas (marianas o de santos) o en novenarios o con frecuencias especiales (tabla 22).

TABLA ESTADÍSTICA № 21

Manda de salir sobre la sepultura el día del entierro

\begin{tabular}{|c|c|c|c|c|}
\hline testador & Juan Martín, portugués, vecino. & $\begin{array}{l}\text { Estevanía Peçano, genovesa, vecina, } \\
\text { viuda de Martín de Morón. }\end{array}$ & Juan Lopes, calderero, francés, vecino. & $\begin{array}{l}\text { Gerónimo Daboçio, curtidor, } \\
\text { genovés vecino. }\end{array}$ \\
\hline reseña documental & 1548, oficio 8 , fo $750 \mathrm{v}$. & 1547, oficio 2, fo $857 \mathrm{rv}$. & 1547, oficio 3, fo $241 \mathrm{rv}$. & 1543 , oficio 5 , fo $1256 r$. \\
\hline testador & $\begin{array}{l}\text { Pedro Perseva de la Cruz, curtidor, } \\
\text { genovés, vecino. }\end{array}$ & $\begin{array}{l}\text { Antono de Hinojos, curtidor genovés, } \\
\text { vecino. }\end{array}$ & $\begin{array}{l}\text { Ysabel Adorno, mujer de Gerónimo } \\
\text { Saluçio, vecina. }\end{array}$ & $\begin{array}{l}\text { Juan Bastardo, calderero, } \\
\text { francés, vecino. }\end{array}$ \\
\hline reseña documental & 1542 , oficio 10 , fo $1005 \mathrm{rv}$ & 1541, oficio 3, fo 847rv. & 1541, oficio 3 , fo 386v. & 1540, oficio 5 , fo $290 \mathrm{v}$. \\
\hline testador & $\begin{array}{l}\text { Juan Martín, portugués, muñidor del } \\
\text { hospital de la Misericordia, vecino. }\end{array}$ & $\begin{array}{l}\text { Luys de Espíndola, hijo del jurado Juan } \\
\text { Bernal de Gallegos, genovés, vecino. }\end{array}$ & $\begin{array}{l}\text { Guiomar Álvares la Gallarda, } \\
\text { portuguesa, mujer de Juan } \\
\text { Domingues, vecina. }\end{array}$ & $\begin{array}{l}\text { Françisco Martín, } \\
\text { portugués, vecino. }\end{array}$ \\
\hline reseña documental & 1540, oficio 5 , fo $405 \mathrm{v}$. & 1539, oficio 7 , fo $357 \mathrm{v}$. & 1538, oficio 7, fo 848rv. & 1538, oficio 2, fo 529rv. \\
\hline testador & $\begin{array}{l}\text { Françisco Adorno, veinticuatro, } \\
\text { genovés, vecino. }\end{array}$ & Hernando Tirado, genovés, vecino. & Juan Fernandes, portugués, estante. & $\begin{array}{l}\text { Juan Álvares, atahonero, } \\
\text { portugués, vecino. }\end{array}$ \\
\hline reseña documental & 1538, oficio 7 , fo 163 rv. & 1537, oficio 3 , fo $416 \mathrm{v}$. & 1536, oficio 5, fo 273rv. & 1535 , oficio 5 , fo $560 \mathrm{v}$. \\
\hline testador & Diego Martín, portugués, estante. & $\begin{array}{l}\text { Doménigo de Mafe, mercader, } \\
\text { genovés, vecino. }\end{array}$ & $\begin{array}{l}\text { Violante Fernandes, portuguesa, } \\
\text { vecina. }\end{array}$ & $\begin{array}{l}\text { Antón Françés, calderero, } \\
\text { francés, estante. }\end{array}$ \\
\hline reseña documental & 1535 , oficio 10 , fo $243 v$. & 1531, oficio 2, fo 459v. & 1528 , oficio 7 , fo $60 \mathrm{v}$. & 1526, oficio 4, fo 59v. \\
\hline testador & $\begin{array}{l}\text { Batysta Bone, tonelero, genovés, } \\
\text { vecino. }\end{array}$ & Juan Peres Peçano, genovés, vecino. & & \\
\hline reseña documental & 1523, oficio 1 , fo $32 v$. & 1490, Bartolomé de Maya, fo 63rv. & & \\
\hline
\end{tabular}

TABLA ESTADÍ́STICA № 22

Manda de salir sobre la sepultura en días especiales o con carácter perpetuo

\begin{tabular}{|c|c|c|c|c|}
\hline día & Candelaria & Encarnación & Todos los Santos & 6 días \\
\hline testador y reseña documental & $\begin{array}{l}\text { Hernando Tirado, genovés, } \\
\text { vecino, } 1537 \text {, oficio } 3 \text {, fo } 416 v \text {. }\end{array}$ & $\begin{array}{l}\text { Catalina la griega, mujer de Pedro Perseva, } \\
\text { 1550, oficio 5, fo ileg. v., y Estevanía Peçano, } \\
\text { 1547, oficio 2, fo 857rv. }\end{array}$ & $\begin{array}{l}\text { Estevanía Peçano, genovesa } \\
\text { viuda de Martín de Morón, } \\
\text { 1547, oficio 2, fo } 857 \text { rv. }\end{array}$ & $\begin{array}{l}\text { Antono Marques, odrero } \\
\text { genovés, vecino, 1543, oficio } \\
7, \text { fo } 477 \mathrm{rv} \text {. }\end{array}$ \\
\hline día & 9 días & 10 días & 13 días & 6 misas semanales \\
\hline testador y reseña documental & $\begin{array}{l}\text { Juan Rodríguez, portugués, } \\
\text { vecino, } 1511 \text {, oficio } 2 \text {, fo } 567 \mathrm{v} \text {. }\end{array}$ & $\begin{array}{l}\text { Juan Martín, portugués, muñidor del } \\
\text { hospital de la Misericordia, vecino, 1540, } \\
\text { oficio 5, fo } 405 \mathrm{v} \text {. }\end{array}$ & $\begin{array}{l}\text { Antono Marques, odrero } \\
\text { genovés, vecino, } 1543 \text {, oficio } \\
7, \text { fo } 477 \mathrm{rv} .\end{array}$ & $\begin{array}{l}\text { Doña Clara Marrufo, } \\
\text { genovesa, mujer de Martín } \\
\text { Dávila, 1542, oficio 3, fo } 624 \text { rv. }\end{array}$ \\
\hline
\end{tabular}

El momento en que se realiza tal salida sobre la sepultura no sigue ninguna regla fija, pues hay quien lo ordena para inmediatamente después del entierro, formando parte del funeral en sí, y hay quienes lo dilatan en el tiempo, a veces, de forma perpetua una vez al año por el aniversario de su muerte o por alguna festividad religiosa de la devoción del muerto. Así hemos documentado un total de veintidós mandas de salir sobre la sepultura el mismo día del entierro, y el resto se reparte entre los seis días siguientes (un caso), los nueve días

\section{Salmos penitenciales}

"Se llama Salmos penitenciales a siete salmos, número simbólico, elegidos de entre todo el Salterio que manifiestan la petición de perdón y de misericordia a Dios". ${ }^{128}$

Sólo hemos documentado un testamento en el cual se haga referencia al rezo de los salmos, y corresponde al que otorga

128 Pérez González, S. Mạ. 2005: 75. 
doña Clara Marrufo, esposa del veinticuatro Martín Dávila Sigüenza, vecina en El Salvador, a fines de 1541, cuando manda que las monjas del Monasterio de Madre de Dios, las del Espíritu Santo, Nuestra Señora de la Victoria, Nuestra Señora de Gracia y Santa Clara recen "por mi ánima vn año los salmos de la penitençia, los quales rezen en los días que ellas quizieren rezallos", y paguen por ello lo que parezca a sus albaceas. ${ }^{129}$ genovés Guillermo Conde de Gavia, vecino en El Salvador, manda a la Cofradía del Nombre de Jesús 500 maravedís de tributo perpetuo de los 900 que le paga Juan de Santiago, vecino, sobre su morada en El Salvador. ${ }^{132}$

En algunas ocasiones el testador deja a criterio de sus albaceas el establecer el número, tipo y lugar de celebración de sus honras fúnebres y exequias.

TABLA ESTADÍSTICA № 23

Funerales a criterio de los albaceas

\begin{tabular}{|c|c|c|}
\hline reseña documental & nombre & albaceas \\
\hline 1521 , oficio 7 , fo $1228 \mathrm{rv}$. & Dạ Ysabel de Espíndola & Marido: Yñigo Lopes de Carrizosa \\
\hline 1521, oficio 3, fo $175 \mathrm{v}$. & Leonís Adorno & Su mujer Dạ María, su suegro Christóval Dávila y su tío Jácome Adorno \\
\hline 1522 , oficio 3 , fo roto $v$. & Antono Roteño & Juan Agustín y Bartolomé Casán, genoveses vecinos \\
\hline 1525, oficio 8 , fo $503 v$. & Juan Peres & Hermanos del Hospital de la Misericordia \\
\hline 1530 , oficio 6 , fo $150 v$. & Diego Martín & Hermanos del Hospital de la Misericordia \\
\hline 1532, oficio 6 , fo 1001 rv. & Pedro Gonçales & Hermanos del Hospital de la Misericordia \\
\hline 1533 , oficio 6 , fo $285 \mathrm{v}$. & Alonso de Cárdenas & Hermanos del Hospital de la Misericordia \\
\hline 1534, oficio 6 , fo $358 \mathrm{v}$. & Pedro Alegrete & Hermanos del Hospital de la Misericordia \\
\hline 1535, oficio 5 , fo $560 v$. & Juan Álvares & Su mujer Benita Garçía y su suegra Catalina Garçía \\
\hline 1535, oficio 3, fo roto $\mathrm{v}$. & Juan Antonio de Mafe & Diego Martín Destorga y el bachiller Juan de la Torre, clérigo \\
\hline 1539, oficio 7 , fo $357 v$. & Luys de Espíndola & Su padre Juan Bernal de Gallegos \\
\hline 1540 , oficio 7, fo $147 \mathrm{rv}$ & María de Acosta & Bartolomé Nuñes de Villaviçençio, en cuya casa vive \\
\hline 1540, oficio 7 , fo $107 \mathrm{rv}$. & Batistina Marques* & Su hermano Antono Marques \\
\hline 1544, oficio 18 , fo 1019 rv. & Antono Hurtado & Hermanos del Hospital de la Misericordia \\
\hline 1546 , oficio 11 , fo 1848 rv. & Françisco Hernandes & Hermanos del Hospital de la Misericordia \\
\hline 1546, oficio 7 , fo 320 rv. & Antono de Prinçe & Ximón de Orique, mercader flamenco vecino de Jerez \\
\hline 1547, oficio 11 , fo $1061 \mathrm{rv}$. & Gonçalo Álvares & Hermanos del Hospital de la Misericordia \\
\hline 1548 , oficio 10 , fo 591 r. & Álvaro Figueira & Su hija Juana Hernandes y Diego Martín de Estorga el viejo \\
\hline
\end{tabular}

\section{Fiestas}

Sólo hemos registrado tres casos de personas que al testar instituyen la celebración de una fiesta por la salvación de su alma o de las de sus familiares. Tales celebraciones se habían de sufragar, al igual que el caso de las capellanías, mediante unos recursos que, dado el carácter perpetuo de tales mandas, solían basarse en la adscripción de un censo perpetuo sobre determinado bien propiedad del finado.

Ordenando cronológicamente tales testamentos nos resulta que el primero de ellos corresponde al genovés Luys Despíndola, vecino, ${ }^{130}$ y el segundo caso que registramos a la genovesa doña Clara Marrufo. ${ }^{131}$ Por último, el curtidor

129 AHMJF, APN, oficio 3, Rodrigo de Cuenca, fo 624rv., 29 de agosto de 1542: apertura del testamento de doña Clara que realiza su marido nueve meses después de su fallecimiento.

130 AHMJF, APN, oficio 7, Luis de Llanos, fo 357v., 2 de mayo de 1539: manda que le hagan una fiesta en el día de la Visitación de Nuestra Señora "en su propio día con sermón de la misma fyesta en el dicho día remenbrança, diziéndole vigilia en la tarde del dicho día de la Visitación... y en otro día", para cuyo fin destina un tributo de 500 maravedíes anuales.

131 AHMJF, APN, oficio 3, Rodrigo de Cuenca, fo 624rv., 29 de agosto de 1542: reconoce en su testamento que su madre, doña Juana, mandó que se hicieran dos fiestas en la iglesia de San Juan Evangelista y para ello dotó 1.000 maravedís de tributo sobre una casa en la calle Tornería,
Predominan, como podemos comprobar, aquellos testadores que dejan a criterio de los hermanos mayores del Hospital de la Misericordia la celebración de sus honras fúnebres (ocho casos). Hay que relacionarlos en particular con los portugueses estantes en Jerez a quienes la enfermedad sorprende en la misma y se ven obligados a otorgar testamento en dicha institución benéfica.

El resto lo deja a elección de familiares (marido, mujer, suegra, hermano, hija) o vecinos (con los que hemos de suponer una especial relación de amistad), benefactores (un caso), clérigos, etc. ${ }^{133}$

y ella como patrona manda que se cumpla y nombra, a su vez, como patrona a doña María de Perea, hermana suya.

132 AHMJF, APN, oficio 5, Rodrigo de Rus, fo 290rv., 25 de marzo de 1546: a condición de que "me fagan çelebrar vna fiesta solene del santíssimo Nonbre de lehsús en su día propio de su misa cantada e con diácono e subdiácono e con su sermón e con toda solenydad en cada vn año perpetuamente para syenpre en el dicho Hospital o donde la dicha hermandad e cofradía toviere casa e sytio en esta çibdad, e con sus vísperas e vigilia e con su responso e oraçión por mi ányma e de mis difuntos".

133 En todos los casos los testadores dejan a la elección de sus albaceas el número, carácter y lugar de los oficios por el alma del difunto, salvo en el caso de Batistina Marques, que hemos señalado con un asterisco para significar que sólo deja a criterio de su hermano el lugar de celebración de tales honras, pues su número y caracteres los fija ella en su testamento. 


\section{Mandas}

Distinguiremos entre mandas materiales por la salvación del alma y mandas materiales (a familiares, a otros personajes con quienes no existe parentesco) y mandas religiosas (y dentro de ellas entre pías y forzosas).
Pro remedio animae. Dado que el objetivo prioritario de todo cristiano es la salvación de su alma, por ello, la primera manda es "Mando mi ánima a Dios que me la crió...", y, al tiempo, se manda a una serie de personas la realización de rogativas por el eterno descanso de la misma. Tales rezos se compensan de distinta manera y los recogemos en la tabla que sigue.

TABLA ESTADÍSTICA № 24

Mandas que se ordenan por la salvación del alma

\begin{tabular}{|c|c|c|c|}
\hline reseña documental & testador & encargado rezos & recompensa \\
\hline 1524, oficio 7, fo $89 v$. & Juan Françés, francés & Monasterio Concepción. & Un ducado \\
\hline 1525, oficio 8 , fo $503 \mathrm{v}$. & Juan Peres, portugués & Pobres del Hospital de la Misericordia. & Un ducado, un sayo, un cosete y unos calzones. \\
\hline 1527, oficio 8, fo 565rv. & Catalina Peçano, genovesa & Su criada María de Vargas. & $\begin{array}{l}200 \text { maravedís y "vnos chapines míos nuevos por algunos cargos que della } \\
\text { tengo e por que ruegue a Dios por mi ánima". }\end{array}$ \\
\hline 1528, oficio 4, fo 743rv. & Juan Terrin, genovés & $\begin{array}{l}\text { Doncella pobre y vecina de su ciudad } \\
\text { de origen (villa de Lapria) elegida por } \\
\text { su tío Pedro Terrin, genovés vecino } \\
\text { de Lapria. }\end{array}$ & 10 ducados para ayuda a su boda, por que ruegue a Dios por su ánima. \\
\hline 1528, oficio 8, fo 485rv. & Juan Fernandes, portugués & $\begin{array}{l}\text { Ana Hernandes, lora, que le ha } \\
\text { servido. }\end{array}$ & Un ducado por que ruegue a Dios por su ánima. \\
\hline 1530, oficio 8, fo 319v. & $\begin{array}{l}\text { Clemente de Prementorio, } \\
\text { genovés }\end{array}$ & $\begin{array}{l}\text { Pobres y Hospital de la Sangre de } \\
\text { Jerez y monjas de la Victoria. }\end{array}$ & $\begin{array}{l}\text { Diez ducados a la Sangre y tres reales a la Victoria por que rueguen a Dios } \\
\text { por su ánima. }\end{array}$ \\
\hline 1531, oficio 4, fo 223rv. & Antonio Fernandes, genovés & Su mujer Catalina Fernandes. & $\begin{array}{l}\text { Un tercio de todos sus bienes por buenas obras y servicios y ruegue a Dios } \\
\text { por su ánima. }\end{array}$ \\
\hline 1532, oficio 10 , fo $910 \mathrm{v}$. & Marcos Gonçales, portugués & $\begin{array}{l}\text { A Bartolomé Hernandes de Alcobilla, } \\
\text { vecino, y a Aguilar, vecino en San } \\
\text { Miguel. }\end{array}$ & $\begin{array}{l}\text { A Bartolomé: un sayo viejo, unos calzones de paño blanco, un camisón y } \\
\text { un paño de cabeza, y a Aguilar una capa vieja prieta, unos zapatos y un } \\
\text { bonete viejo. En ambos casos por amor de Dios y rueguen }\end{array}$ \\
\hline 1533 , oficio 3 , fo roto rv. & Domingo Hernandes, portugués & $\begin{array}{l}\text { Los frailes del Monasterio Nuestra } \\
\text { Señora de Guía. }\end{array}$ & Un ducado para "la obra de la dicha capilla" y rueguen a Dios por su alma. \\
\hline 1535 , oficio 5 , fo roto rv. & Bernaldo Guinote, francés & A Bernaldina, hija del peinero. & $\begin{array}{l}\text { Una saya de paño que cueste hasta dos ducados por que ruegue a Dios } \\
\text { por su ánima. }\end{array}$ \\
\hline 1536, oficio 7 , fo $359 \mathrm{v}$. & Antono Marques, genovés & $\begin{array}{l}\text { Su hermana Batistina Marques, mujer } \\
\text { de Jerónimo, genovés vecino de El } \\
\text { Puerto. }\end{array}$ & 3.000 maravedís por que ruegue a Dios por su ánima. \\
\hline 1537, oficio 2, fo 728rv. & María Adorno, genovesa & $\begin{array}{l}\text { A Teresa Sanches y a su hija. } \\
\text { "a las presonas necesitadas que } \\
\text { Françisco Adornio e doña Catalina, } \\
\text { muger de Bartolomé de Ávila } \\
\text { quizieren..." }\end{array}$ & $\begin{array}{l}\text { Mil maravedís cada año durante toda su vida, por que rueguen a Dios por } \\
\text { su ánima. } \\
\text { Diez mil maravedís por que rueguen a Dios por su ánima. }\end{array}$ \\
\hline 1537, oficio 3, fo $416 \mathrm{v}$. & Hernando Tirado, genovés & $\begin{array}{l}\text { Su cuñado Juan Lopes de Santiago. } \\
\text { Su sobrino Alonso Tirado. }\end{array}$ & $\begin{array}{l}\text { "vna capa e vn sayo de Londres nuevo mío" por que ruegue a Dios por su } \\
\text { alma. } \\
\text { Un esclavo negro, Antón, y una mula de atahona "e toda la herramienta } \\
\text { e xarçias que en my casa está de las atahonas syn los asientos y la leña } \\
\text { de gavillas e aceituna que en mi casa está para quemar e que por todo } \\
\text { lo susodicho... pague doze mill maravedis", por que ruegue a Dios por su } \\
\text { alma }\end{array}$ \\
\hline 1538, oficio 7, fo $163 \mathrm{rv}$ & Françisco Adorno, genovés & $\begin{array}{l}\text { Encarga a su mujer doña Ana "que } \\
\text { de mis bienes vista a Garçía Martín, } \\
\text { onbre pobre que está en nuestra } \\
\text { casa...". }\end{array}$ & $\begin{array}{l}\text { "...y ella lo tenga los días de su vida e le dé su cama e de comer de mis } \\
\text { bienes durante sus días... por que el dicho Garçía Martín ruegue a Dios por } \\
\text { mi ánima". }\end{array}$ \\
\hline 1538, oficio 2, fo $529 \mathrm{rv}$ & Françisco Martín, portugués & Su madre Beatris Martín. & Un ducado por que ruegue a Dios por su ánima. \\
\hline 1538, oficio 7, fo 848rv. & $\begin{array}{l}\text { Guiomar Álvares la Gallarda, } \\
\text { portuguesa }\end{array}$ & $\begin{array}{l}\text { Ana, hija de Miguel Benites de } \\
\text { Lebrixa difunto y de Ysabel García, sus } \\
\text { vecinos. }\end{array}$ & Un colchón de los de su cama por que ruegue a Dios por su ánima. \\
\hline 1539, oficio 7 , fo 365rv. & Françisco Martín, flamenco & $\begin{array}{l}\text { María, hija de Juan Ramos, calle } \\
\text { Antona de Dios }\end{array}$ & 1000 maravedís por que ruegue a Dios por su alma. \\
\hline $\begin{array}{l}\text { 1539, oficio 5, fo } \\
\text { 1073rv. }\end{array}$ & Benito Restrojo, portugués & $\begin{array}{l}\text { Pobres Monasterio Espíritu Santo de } \\
\text { Olivencia. } \\
\text { Prima Catalina Váez, hija de Ynés } \\
\text { Domingues, su tía -hermana de su } \\
\text { madre-. }\end{array}$ & $\begin{array}{l}2.000 \text { maravedís para que rueguen a Dios por su ánima. } \\
5.000 \text { maravedís por deuda y por que ruegue a Dios por su ánima. }\end{array}$ \\
\hline
\end{tabular}




\begin{tabular}{|c|c|c|c|}
\hline reseña documental & testador & encargado rezos & recompensa \\
\hline 1541, oficio 3, fo 386v. & Ysabel Adorno, genovesa & $\begin{array}{l}\text { Ysabel, hija de Antón Dionís y Benita } \\
\text { Gonçales. }\end{array}$ & $\begin{array}{l}5.000 \text { maravedís por amor y ruegue... y por servicios de Benita Gonçales; } \\
\text { que se los den para su boda, y si muere antes, se los den a su hermana } \\
\text { Elvira, y si esta muere antes, que se los den a Benita }\end{array}$ \\
\hline 1541, oficio 3, fo 847rv. & Antono de Hinojos, genovés & Su mujer, Catalina de la Çerda. & $\begin{array}{l}\text { Un soberado de las casas de su morada mientras viva, por que ruegue a } \\
\text { Dios por su ánima. }\end{array}$ \\
\hline 1542, oficio 3, fo $624 r v$. & Clara Marrufo, genovesa & Ana Sanches, beata. & 10.000 maravedís por que ruegue a Dios por su ánima. \\
\hline $\begin{array}{l}\text { 1542, oficio 5, fo } \\
\text { 1031rv. }\end{array}$ & Catalina la griega, genovesa & $\begin{array}{l}\text { Hermandad y Cofradía del Sto } 0 \\
\text { Sacramento y emparedadas de El } \\
\text { Salvador }\end{array}$ & Seis reales por que rueguen a Dios por su ánima. \\
\hline 1544, oficio 2, fo 591rv. & Juan Vaes, portugués & $\begin{array}{l}\text { Hermandad del Sto Sacramento de } \\
\text { San Dionisio. }\end{array}$ & Un ducado por que los hermanos rueguen a Dios por su alma. \\
\hline 1545, oficio 5, fo ileg. v. & Gomes Fernandes, portugués & $\begin{array}{l}\text { Miguel Ruys, portugués, que al } \\
\text { presente reside en Jerez. }\end{array}$ & $\begin{array}{l}\text { Una capa, un sayo de paño fino negro, unas calzas, una gorra y un } \\
\text { talabarte que tiene en su casa, más } 3 \text { ducados en dineros en su tierra, } \\
\text { y unos zapatos de cordobán "por cargo e amor que le tengo e por que } \\
\text { ruegue a Dios por mi ánima". }\end{array}$ \\
\hline 1545, oficio 8 , fo 682 rv. & Liquina de Espíndola, genovesa & Su marido, Françisco de Morales. & $\begin{array}{l}\text { El tercio de todos sus bienes "por amor que le tengo y buena compañia } \\
\text { que me a fecho y por que ruegue a Dios por mi ánima" }\end{array}$ \\
\hline 1546, oficio 2 , fo $357 \mathrm{v}$. & Françisco Martín, portugués & María Flores, vecina. & $\begin{array}{l}\text { Dos ducados en dineros, más un colchón y todo el hato suyo "por serviçio } \\
\text { que me a fecho en mis enfermedades e porque me acuerdo de buenas } \\
\text { obras que he resebido", por que ruegue a Dios por su alma. }\end{array}$ \\
\hline 1546, oficio 8 , fo 292 rv. & Berenguela Gentil, genovesa & Catalina Gonçales, ama de su casa. & $\begin{array}{l}\text { Unas faldillas leonadas usadas y una camisa blanca por que ruegue a Dios } \\
\text { por su ánima. }\end{array}$ \\
\hline 1547, oficio 8, fo $254 \mathrm{v}$. & $\begin{array}{l}\text { Pedro Perseva de la Cruz, } \\
\text { genovés }\end{array}$ & $\begin{array}{l}\text { Cofradía del Nombre de Jesús. } \\
\text { Clara de la Cruz, su sobrina, hija de su } \\
\text { hermano Doménigo de la Cruz y mujer } \\
\text { de Batista Liçora, vecina de Génova } \\
\text { "sy fuere biva". }\end{array}$ & $\begin{array}{l}500 \text { maravedís por el acompañamiento "que me an de faser y por que } \\
\text { rueguen a Dios por mi ánima". } \\
280 \text { ducados "por cargo que yo tenía del dicho su padre y porque es mi } \\
\text { sobrina y por que ruegue a Dios por mi ánima". }\end{array}$ \\
\hline 1547, oficio 5, fo 241rv. & Juan Lopes, francés & $\begin{array}{l}\text { Antón, su sobrino, hijo de su hermana } \\
\text { Margarida. } \\
\text { Juana, su hermana francesa, "que está } \\
\text { casada en Françia". } \\
\text { Guillén, mozo que está en su casa. }\end{array}$ & $\begin{array}{l}\text { "Quinze ducados por el devdo y amor que le tengo y ruegue a Dios por mi } \\
\text { ánima". } \\
20 \text { ducados por deuda y "amor que le tengo" y ruegue a Dios por su } \\
\text { ánima. } \\
6 \text { ducados por el servicio y por que ruegue a Dios por su ánima. }\end{array}$ \\
\hline $\begin{array}{l}\text { 1547, oficio 12, fo } \\
\text { 328rv. }\end{array}$ & Juan Brut, inglés & $\begin{array}{l}\text { Monjas de San Cristóbal de Jerez } \\
\text { (Orden de San Agustín). } \\
\text { Françisco Garçía de las Cañas, su } \\
\text { suegro. }\end{array}$ & $\begin{array}{l}4 \text { ducados en limosna para que rueguen por su alma. } \\
15 \text { ducados por cargo que le tiene y ruegue a Dios por su ánima. }\end{array}$ \\
\hline 1547, oficio 2, fo 857rv. & Estevanía Peçano, genovesa & $\begin{array}{l}\text { Sacristana del Monasterio Espíritu } \\
\text { Santo. } \\
\text { Su prima Ana de Mendoza. } \\
\text { Su sobrina Ysabel Lopes, mujer de } \\
\text { Bartolomé de Estorga. } \\
\text { Alonso Peçano, hijo de Alonso Peçano, } \\
\text { su sobrino. } \\
\text { Su hermana Catalina Peçano. } \\
\text { Ysabel Lopes, hija de Alonso Peçano. }\end{array}$ & $\begin{array}{l}\text { Unas cuentas negras grandes por que ruegue a Dios por su alma } \\
\text { Un arca pequeña de ciprés por que ruegue a Dios por su alma } \\
\text { Un brasero de hierro por que ruegue a Dios por su alma } \\
\text { Una colcha, una sábana, una almohada y un paño de rostro blanco por } \\
\text { que ruegue a Dios por su alma. } \\
\text { Una faldilla prieta con un ropón de Contray por que ruegue a Dios por su } \\
\text { ánima. } \\
\text { Un manto de sarga y una camisa nueva "de las que yo tengo en mi arca, la } \\
\text { más rica, e vn anillo de oro, el mejor" por que ruegue }\end{array}$ \\
\hline 1548, oficio 7, fo $237 \mathrm{v}$. & Juan Martín, portugués & $\begin{array}{l}\text { Los presos de la cárcel al tiempo de } \\
\text { su muerte. }\end{array}$ & 375 maravedís por que rueguen a Dios por su alma. \\
\hline
\end{tabular}

Observamos que las mandas se suelen concretar en: dinero exclusivamente (la mayoría: veinte casos); ropa solamente (siete casos); ropa y dinero (tres); bienes sin especificar (dos, que se refieren al usufructo del tercio de todos sus bienes que realiza un cónyuge a favor del otro); mobiliario doméstico (cuatro); parte de la vivienda (un caso); mantenerlo durante su vida (un caso) y bienes varios (esclavo, mulo y herramientas, un caso).

La mayoría se encargan a familiares (cónyuge, hermanos, sobrinos,..., 19 casos); criados (cinco); vecinos (seis); compatriotas (uno que reside en Jerez y otro que reside en su lugar de origen); instituciones religiosas (monasterios y cofradías, ocho casos; emparedadas y beatas, dos); asistenciales (dos a hospitales); de reclusión (uno).

En suma, es una muestra más de las creencias y devociones que poseían tales individuos y que se manifiestan además en las mandas relativas a las misas destinadas a conseguir la salvación de su ánima.

A familiares. Las disposiciones testamentarias a favor de familiares reflejan de manera nítida el afecto y buena relación existente entre el testador y los familiares que le sobreviven y se manifiesta en la manda de diversos objetos, tierras, ganado o dinero. A menudo conllevan la obligación por parte del beneficiario de rogar a Dios por el alma del fallecido. 
Predominan las mandas a los familiares en primer grado (sobre todo a los hermanos e hijos, con siete casos, seguidos por los cónyuges -marido, cinco casos y mujer, otros cinco-, aunque los sobrinos (y los hijos de éstos) se sitúan también con diez casos a un nivel superior), aunque suelen ser menos frecuentes hacia los progenitores (uno a ambos y dos a la madre). Los familiares en segundo grado se sitúan a nivel inferior (salvo el caso de los sobrinos): dos a los primos y uno a un nieto, mientras que la familia política también está presente (dos veces a cuñado y una a suegro).

Los bienes que se legan ofrecen una gran variedad: desde cantidades en metálico (once casos y con cantidades variables: desde seis ducados a 280 , que era una cantidad apreciable, y no digamos los 150.000 maravedís que manda la genovesa doña Clara Marrufo a su marido), pasando por el usufructo de sus bienes mientras viva (cuatro casos), infraestructura artesanal (una casa tenería), semovientes (esclavos y animales, seis casos), mejoría de la legítima (usualmente el tercio y quinto, siete casos), condonación de deudas (un caso) y terminando por joyas (cadena, anillo,...), ropa (camisa, manto,...) y objetos del mobiliario doméstico (sábanas, faldas, colchones, braseros, ...). Además hay dos casos que no especifican la naturaleza de tales bienes.

A otros. Incluimos en este apartado todas aquellas mandas que tienen como beneficiarios a personas del entorno o no del testador, pero sin ningún grado de parentesco con el mismo.

Hallamos una enorme variedad entre los beneficiarios de tales mandas: vecinos (la mayoría, 31 casos); pobres y huérfanos (siete); servicio doméstico (criados y amas de cría, cinco, más dos casos de hijos de las amas, y una esclava); compatriotas (al menos cuatro casos); dos casos de cautivos y otros dos de beatas. Con un solo registro encontramos la sacristana de un monasterio, el que quiere que sea tutor de sus hijos y una persona de Sevilla que conoce la esposa del ordenante.

En cuanto a los bienes que se mandan volvemos a encontrarnos el mismo panorama que con la tabla anterior: un poco de todo. Predominio del dinero en efectivo (con cantidades muy variadas: desde dos ducados hasta 550; suponen un total de 37 casos; a veces es dinero con ropa); ropa (catorce casos, incluyendo a veces calzado) y el mobiliario de casa (cinco registros). El resto tiene una presencia testimonial: su parte en un animal, trigo, herramienta, y lo que sí tenía más valor (como unas viñas y una esclavita). A ello hay que sumar un caso en que se ordena se vista y alimente a un pobre con el producto de sus bienes.

Los motivos para realizar tales mandas son asimismo variados, aunque es clara la primacía de la oración por la salvación del ánima del finado (catorce casos). También (y ello es especialmente visible en el caso de las mandas a doncellas) mandar dinero para la boda o para el rescate de cautivos; por amor de Dios; por descargo de la conciencia o porque le atiende durante la enfermedad que está sufriendo.

Mandas pías. Podríamos otorgar dicho calificativo a todas aquellas disposiciones testamentarias que poseen un objetivo piadoso o benéfico.

En ellas se registra un claro predominio de las mandas a las instituciones benéficas, en primer lugar, las destinadas al Hospital de la Misericordia (con doce mandas), seguida por el Hospital de la Sangre (seis), el Hospital de San Bartolomé y Santa Catalina (cuatro), y el de Nuestra Señora de los Remedios y Nuestra Señora del Pilar (un caso cada uno). Se sitúan a continuación los monasterios: Nuestra Señora de la Victoria (dos); San Francisco (un caso); Madre de Dios (uno) y San Cristóbal (uno); las Cofradías (cera del Santo Sacramento del Salvador -seis casos-; la Limpia Concepción -dos-; cera del Santo Sacramento de las iglesias de San Miguel, San Lucas y Santiago, un caso cada una, y las hermandades del Nombre de Jesús y los Niños de la Doctrina, ${ }^{134}$ un caso cada una).

Además hemos de reseñar una manda a las emparedadas de San Salvador, y las mandas a las iglesias de la tierra de origen de algunos inmigrantes (San Alberto y Santa Guarda en Génova; San Nicolás de Lapria, San Roque de Lapria, iglesia de Para e iglesia de Tove; Monasterios de la Madre de Dios y San Francisco de Lisboa y las iglesias de San Mamed y San Nicolás de Lisboa).

Las mandas fluctúan entre dinero en efectivo (desde 32 ducados hasta un real), pasando por ropas diversas (sábanas, manteles, capas, sayos,...), mobiliario (colchón), sementera del año, comida para los pobres, etc.

Mandas forzosas. Como su propio nombre indica, eran mandas que se realizaban de manera forzosa. Por tanto, no podían faltar en ningún testamento y existían unas aportaciones mínimas para cada institución destinataria de las mismas, que estaba establecida en un maravedí. En algunos casos los testadores ordenan el pago de cantidades mayores a tales órdenes e iglesias.

Las mandas forzosas que nunca faltan en los testamentos son aquellas que se ordenan a la Cruzada, la Trinidad y Santa Olalla (para la redención de cautivos cristianos), y la iglesia de Santa María la Mayor de Sevilla "por ganar los perdones e por dispensaçión de mi ánima...".

Pero en algunos casos hallamos mandas expresas a la Orden de la Merced (también destinadas a redimir cautivos), pero no en todos los casos (sólo en nueve de los testamentos analizados aparece dicha manda a los frailes mercedarios, lo que representa aproximadamente un ocho por ciento del total). La explicación de esto parece proceder del hecho de que Santa Olalla (Eulalia) tuviera una mayor presencia en el Reino de Sevilla que la Merced, aunque los componentes de dicha Orden eran monjes mercedarios calzados asimismo y también con la misma finalidad: la redención de cautivos. ${ }^{135}$ De manera curiosa, algún testador

\footnotetext{
134 No tenemos clara la condición de hermandad de los Niños de la Doctrina Cristiana, pues el testador (el mercader genovés Juan Çigala) se refiere a ellos de la manera siguiente: "... aconpañen mi cuerpo... los curas de la yglesia de San Marcos... a la hermandad e cofradía de la Veracruz desta çibdad con los niños de la dotrina christiana e la hermandad del Nonbre de Ihesús...".

135 Pujante Martínez, A. 2004. "Los testimonios materiales de la orden de la Merced y su evolución desde época medieval hasta la actualidad", AlbercA, 2: 189-206, afirma "La orden se constituyó como Orden Redentora de la propia de la casa real de Aragón en 1218, en el altar mayor, erigido sobre la tumba de Santa Eulalia, de la Catedral de la Santa Cruz de Barcelona; siendo una de sus denominaciones, la de la Orden de Santa Eulalia" (p. 191). Morote Pérez, P. 1741. Antigüedad y blasones de la ciudad de Lorca y Historia de Santa María la Real de las Huertas: 291: "El convento de Santa Olalla, o de la Merced, es el más antiguo de esta ciudad...".
} 
ordena mandas a ambas, Santa Olalla y la Merced (caso del tonelero genovés Bernaldo Savio, en 1549).

También localizamos algún ejemplo de manda forzosa a la capilla de la Virgen de la Antigua en la catedral de Sevilla, como el caso de la genovesa Catalina la griega, ${ }^{136}$ esposa del curtidor genovés Pedro Perseva de la Cruz, quien en su testamento de 1546 manda a la Cruzada, Santa Olalla, la Trinidad, la Merced, Nuestra Señora de la Antigua y a San Lázaro la costumbre. También hace lo mismo el tonelero citado, Bernaldo Savio en $1549,{ }^{137}$ y cinco casos más (hasta un total de siete).

\section{CONCLUSIONES}

A la religiosidad de los extranjeros vecinos o estantes en Jerez de la Frontera, hemos intentado acercarnos desde el análisis de sus testamentos.

La muerte era una realidad omnipresente en la vida de aquellas personas de fines del siglo $x V$ y comienzos del XVI (la mortalidad por causas naturales, pero asimismo la incidencia de la mortalidad por complicaciones en el parto y postparto, de la mortalidad infantil y la catastrófica por razón de las guerras, epidemias y hambrunas) y se le temía $y$, por ello, se preparaba el enfermo en lo posible ante su cercanía (normalmente se redactaba in articulo mortis, aun cuando hallamos casos de supervivencia tras haber testado), otorgando testamento. En dichos documentos siempre se recalcaba el hecho de hallarse en perfectas facultades mentales, se especificaba el lugar del entierro, cómo había de conformarse el cortejo fúnebre, así como las honras y exequias que se habían de celebrar para acelerar su paso por el Purgatorio y alcanzar cuanto antes el cielo. Además nunca faltaba la declaración de deudas y algunas veces la de dote y arras, y se terminaba con las mandas (a familiares, amigos, conocidos, pobres, huérfanos, instituciones benéficas, iglesias, monasterios, etc., las llamadas mandas forzosas, otras de carácter artístico, etc.), la revocación de anteriores testamentos y el nombramiento de albaceas y herederos.

Tales documentos nos informan asimismo sobre la pertenencia de personas a cofradías y hermandades, sobresaliendo sin duda la de los genoveses del Nombre de Jesús como creación de tales inmigrantes ligures en la ciudad. Hubo otras a las que pertenecieron extranjeros, pero no con el carácter exclusivo ni de fundación realizada por un colectivo foráneo.

En definitiva, creemos poder afirmar que los extranjeros compartían con los naturales de la ciudad una misma religiosidad (la creencia y devoción a Dios, la Virgen, los santos y santas, la creencia en el Purgatorio, las mandas testamentarias, etc.). Y a partir de ahí, podríamos preguntarnos si esta situación se debía a que existía una religiosidad común a toda la Europa de entonces, si es que la aprendían en la ciudad (cosa perfectamente razonable en el caso de los hijos, nietos, etc., de los primeros inmigrantes), etc.

136 AHMJF, APN, oficio 5, Rodrigo de Rus, fo ileg v., 2 de enero de 1550 (fecha que corresponde a la apertura del testamento que Catalina otorgó en 1546).

137 AHMJF, APN, oficio 5, Rodrigo de Rus, fo 265rv., 20 de marzo de 1549.
A título de hipótesis apuntamos que tal comunidad de creencias religiosas obedecía fundamentalmente a la existencia de una religiosidad común entre los países, zonas y ciudades de origen de tales inmigrantes con la que reinaba en Castilla. No traían una religiosidad distinta de la religiosidad castellana, aun cuando algún elemento (caso de la devoción a algún santo en particular o la participación en cofradías o hermandades) pudiera tener algún elemento de especial significación no por el hecho de ser extranjeros, sino quizá por el de encontrarse en Andalucía y, en concreto, en el Reino de Sevilla y vivir de una manera especial las celebraciones de Semana Santa y otras festividades del año litúrgico.

\section{BiBLIOGRAFÍA}

Alfonso Santorio, P. 1997. "Religiosidad y nobleza. La fundación de capellanías. Un ejemplo malagueño", en Religiosidad popular en España: 193-216, San Lorenzo del Escorial.

Arranz Guzmán, A. 1986. "La reflexión sobre la muerte en el medievo hispánico, ¿continuidad o ruptura?”, En la España Medieval V, v. I, Universidad Complutense de Madrid.

Baldó Alcoz, J. 2006. "Las misas post mortem: simbolismos y devociones en torno a la muerte y el más allá en la Navarra bajomedieval", Zainak 28: 353-374.

Bejarano Rubia, A. 1988. "La elección de sepultura a través de los testamentos medievales murcianos", Miscelánea Medieval Murciana 15, Universidad de Murcia.

Bello León, J. M. 1994. Extranjeros en Castilla (1474-1501), Universidad de La Laguna.

Carlé, Mà. C. 1993. Una sociedad del siglo XV. Los castellanos en sus testamentos, Buenos Aires.

Domínguez Ortiz, A. 1981. Autos de la Inquisición de Sevilla (siglo XVII), Sevilla.

Dopico Gutiérrez del Arroyo, F. “Desarrollo económico y social y mortalidad infantil. Diferencias regionales (1860-1950)", en http://ddd. uab.cat/pub/dynamis/02119536v5-6p381.pdf.

Fernández Conde, F. J.: La religiosidad medieval en España. Baja Edad Media (siglos XIV y XV). Oviedo: Trea, 2011.

García Fernández, M. 1996. Los castellanos y la muerte. Religiosidad y comportamientos colectivos en el Antiguo Régimen, Junta de Castilla-León, Valladolid.

García Guzmán, Mạ del M. y Abellán Pérez, J. 1997. La religiosidad de los jerezanos según sus testamentos (siglo XV), Cádiz.

García Pedraza, A. 2002. Actitudes ante la muerte en la Granada del siglo XVI, Universidad de Granada.

Hinojosa Montalvo, J. 1981. "Las relaciones comerciales entre Valencia y Andalucía en la Baja Edad Media", Actas /I Coloquio Historia Medieval de Andalucía: 249-267, Sevilla.

Jaime Piqueras, J. 2012. “Disposiciones espirituales y modelo familiar en los testamentos medievales valencianos: una aproximación económica, 1381-1450", HID 39: 241-258.

Martínez Gil, F. 2000. Muerte y sociedad en la España de los Austrias, Universidad de Castilla La Mancha.

Mingorance Ruiz, J. A. 2012. "Aportación documental a la historia de la Cofradía del Nombre de Jesús de Jerez de la Frontera", en Religiosidad sevillana. Homenaje al profesor José Sánchez Herrero: 339-365, Sevilla.

Miura Andrades, J. M. 1987. "Las fundaciones de la O. P. en Andalucía (1236-1591). Un análisis cronológico", en Actas del Primer Congreso Internacional sobre los Dominicos y el Nuevo Mundo: 73-99, Madrid.

Morote Pérez, P. 1741. Antigüedad y blasones de la ciudad de Lorca y Historia de Santa María la Real de las Huertas.

Pérez González, S. Ma. 2005. Los laicos en la Sevilla bajomedieval. Sus devociones y cofradías, Huelva, Universidad de Huelva. Ibídem. 2000. "Las Cofradías de Sevilla en el siglo XV: La Cofradía de la Sangre", en I Simposio sobre Hermandades de Sevilla y su Provincia: 29-45, Sevilla.

Pomar Rodil, P. J. y Mariscal Rodríguez, M. Á. 2004. Jerez de la Frontera. Guía artística y monumental, Jerez, Sílex Ediciones. 
Pons Alós, V. 1987. Testamentos valencianos en los siglos XIII-XVI. Testamentos, familia y mentalidades en Valencia a finales de la Edad Media, Tesis doctoral inédita, Valencia. Ibídem. 1995. "Documento y sociedad: el testamento en la Valencia medieval", Estudis Castellonencs, no 6: 1101 y ss, Castelló.

Pujante Martínez, A. 2004. "Los testimonios materiales de la orden de la Merced y su evolución desde época medieval hasta la actualidad", AlbercA, 2: 189-206.

Rojas Vaca, Ma D. 1995. "Notariado público y documento notarial en Jerez de la Frontera en el tránsito a la modernidad", I Jornadas sobre el Notariado en Andalucía: 291-338, Sevilla.

Romero Abao, A. del R. 1989 "La fiesta del Corpus Christi en Sevilla en el siglo XV", en La religiosidad popular. Hermandades, romerías y santuarios: $19-32$, Sevilla.
Romero Bejarano, M. 2005. "La construcción de la capilla de la Limpia Concepción del monasterio de San Francisco de Jerez de la Frontera", Actas del Simposium La Inmaculada Concepción en España: religiosidad, historia y arte: 1007-1029.

Romero Mensaque, C. J. 2012. "Un estado de la cuestión sobre el Rosario y sus cofradías en España”, en Religiosidad sevillana...: 178-179, Sevilla.

Sánchez Herrero, J. 2001. "Vivir y morir en Estepa en el siglo XVII". En Actas de las IV Jornadas sobre Historia de Estepa. La vicaría eclesiástica de Estepa: 239-283, Estepa. Ibídem. 1992. “La Iglesia y la religiosidad en la diócesis de Zamora a finales del siglo XV" en Zamora, su entorno y América, Diputación de Zamora.

Sánchez Saus, R. 1988. "De los patrimonios nobiliarios en la Andalucía del siglo xv. Los bienes del caballero jerezano Martín Dávila (1502)", Anuario de Estudios Medievales 18: 469-485. 